\title{
Estudo TAXoNôMico de STYlosanthes (LegUMinOSAE - Papilionoideae - Dalbergieae) em Mato Grosso do Sul, Brasil ${ }^{1}$
}

\author{
Leila Carvalho da Costa ${ }^{2,5}$, Ângela Lúcia B. Sartori ${ }^{3}$ \& Arnildo Pott ${ }^{4}$
}

\begin{abstract}
Resumo
(Estudo taxonômico de Stylosanthes (Leguminosae - Papilionoideae - Dalbergieae) em Mato Grosso do Sul, Brasil) Stylosanthes é um gênero pantropical constituído por 50 espécies, sendo a metade destas registradas no Brasil. Neste estudo é apresentado o levantamento das espécies de Stylosanthes ocorrentes em Mato Grosso do Sul, por meio de análises de material depositado em herbários nacionais e de coletas efetuadas no estado. Stylosanthes está representado em Mato Grosso do Sul por 17 espécies, distribuídas em duas seções. Stylosanthes seção Styposanthes está representada por cinco espécies: S. bracteata, S. capitata, S. hamata, S. macrocephala e S. scabra e Stylosanthes seção Stylosanthes por 12 espécies: S. acuminata, S. gracilis, S. grandifolia, S. guianensis, S. hippocampoides, S. humilis, S. linearifolia, S. longiseta, S. maracajuensis, $S$. montevidensis, S. nunoi e $S$. viscosa. São ocorrências inéditas para o estado: S. capitata, S. hamata, $S$. hippocampoides, S. humilis, S. linearifolia, S. macrocephala, S. montevidensis e S. nunoi. Em Mato Grosso do Sul verifica-se que as espécies de Stylosanthes podem ocorrer no cerrado, cerradão, campo sujo e chaco. Palavras-chave: flora, taxonomia, leguminosas, sistemática.
\end{abstract}

\section{Abstract}

(Taxonomic study of Stylosanthes (Leguminosae-Papilionoideae-Dalbergieae) in Mato Grosso do Sul, Brazil) Among those used species is the genus Stylosanthes is a pantropical genus with 50 species, half of them occurring in Brazil. This study presents a survey of Stylosanthes species of the state of Mato Grosso do Sul, through analysis of material from national herbaria and field collections. Stylosanthes is represented in Mato Grosso do Sul by 17 species, distributed into two sections. Stylosanthes section Styposanthes is represented by five species: S. bracteata, S. capitata, S. hamata, S. macrocephala and S. scabra and Stylosanthes section Stylosanthes by 12 species: Stylosanthes acuminata, S. gracilis, S. grandifolia, S. guianensis, S. hippocampoides, S. humilis, S. linearifolia, S. longiseta, S. maracajuensis, S. montevidensis, S. nunoi and S. viscosa. As new occurrences for the state are pointed out: S. capitata, S. hamata, S. hippocampoides, $S$. humilis, S. linearifolia, S. macrocephala, S. montevidensis and S. nunoi. Species of Stylosanthes in Mato Grosso do Sul occur in cerrado savanna, cerrado-woodland, grassland and Chaco.

Key words: flora, taxonomy, legumes, systematic.

\section{INTRODUÇÃO}

Stylosanthes é um gênero megatérmico e pantropical, com cerca de 50 espécies descritas (Lewis et al. 2005). No Brasil ocorrem 25 espécies, que são encontradas principalmente no cerrado (Brandão \& Costa 1979).

O gênero pertencia à tribo Aeschynomene (Rudd 1981), porém recentemente passou à tribo Dalbergieae, que abrange espécies arbóreas, lianas e herbáceas (Lewis et al.
2005). Nessa nova classificação foram agrupadas na tribo representantes que possuem microorganismos fixadores de nitrogênio.

Stylosanthes foi descrito em 1788 por O. Swartz, com duas espécies, $S$. procumbens Sw. (= S. hamata (L.) Taubert) e S. viscosa Sw. Posteriormente, Vogel 1838 (apud Brandão \& Costa 1982) estudou o gênero dividindo-o em duas seções, Eustylosanthes e Styposanthes com base na presença ou

Artigo recebido em 10/2007. Aceito para publicação em 06/2008.

${ }^{1}$ Parte da dissertação de Mestrado da primeira autora no Programa de Pós-graduação em Biologia Vegetal - Universidade Federal de Mato Grosso do Sul

${ }^{2}$ Programa de Pós-graduação em Biologia Vegetal - Universidade Federal de Mato Grosso do Sul

${ }^{3}$ Universidade Federal de Mato Grosso do Sul; Centro de Ciências Biológicas e da Saúde; Departamento de Biologia; Laboratório de Botânica; Cidade Universitária; 79070-900; C.P. 549, Campo Grande, MS, Brasil

${ }^{4}$ Embrapa Gado de Corte, Campo Grande, MS.

${ }^{5}$ Autor para correspondência: costa_mame@yahoo.com.br 
ausência de um eixo rudimentar plumoso na base das flores e posteriormente dos frutos. Mohlenbrock (1958) efetuou a revisão do gênero, reconhecendo 25 espécies, as quais agrupou em duas seções: $S$. seção Stylosanthes (14 spp) e $S$. seção Astyposanthes (11 spp). Posteriormente, novas adições foram efetuadas por Mohlenbrock (1963) no gênero, com acréscimo de cinco táxons totalizando 30 espécies, distribuídas pela América do Sul, África e Austrália. A tipificação do gênero e de suas seções têm sido objeto de discussão ao longo de sua história. Segundo Kirkbride \& Kirkbride (1987) Stylostanthes seção Eustylosanthes e $S$. seção Astyposanthes são sinônimos de $S$. seção Stylosanthes, classificação seguida por Costa (2006).

Dentre os estudos taxonômicos realizados com Stylosanthes no Brasil destacam-se os de Brandão \& Costa (1979) e Costa (2006). Estudos regionais foram efetuados por Brandão \& Costa (1982) para as espécies de Minas Gerais e por Sousa et al. (2003) para o Ceará.

O presente trabalho teve como objetivo realizar o estudo taxonômico de Stylosanthes para o Mato Grosso do Sul, fornecendo chave para identificação das espécies, bem como descrições, ilustrações e dados atualizados de distribuição geográfica, de formações vegetais e fenologia.

\section{Material e Métodos}

Este estudo foi baseado na análise de exsicatas pertencentes a nove herbários nacionais e em espécimes coletados e observados em localidades distintas do estado de Mato Grosso do Sul. Foram analisadas exsicatas dos herbários CGMS, COR, DDMS, HMS, MBM, PAMG, SP e RB (acrônimos de acordo com Holmgren et al. 1990).

A nomenclatura morfológica adotada nas descrições foi baseada em Font Quer (1953), Radford et al. (1974), Rizzini (1977), Harris \& Harris (1994). Quanto à forma os estiletes foram classificados como uncinado, espiralado e encurvado. Neste estudo a circunscrição das seções segue Costa (2006), categorias infra- específicas não foram consideradas. As descrições do gênero e das espécies correspondem à amplitude de variação morfológica dos espécimes coletados no estado de Mato Grosso do Sul.

As informações acerca da distribuição geográfica e do ambiente preferencial das espécies foram obtidas das observações de campo e das etiquetas que acompanham o material herborizado. As formações vegetais foram classificadas de acordo com IBGE (1992). Os mapas de distribuição foram confeccionados com o uso dos softwares Microsoft EXCEL e Diva-Gis 5.2. Os materiais analisados citados após as descrições das espécies se enquadram em selecionados e examinados. Os dados de fenologia foram obtidos das observações de campo e das etiquetas de todo o material herborizado examinado.

As mensurações foram efetuadas com paquímetro eletrônico digital Worker. As ilustrações foram confeccionadas com o auxílio de estereomicroscópio Zeiss, utilizando materiais coletados em campo e quando necessário herborizados e reidratados.

\section{Resultados e Discussão}

Em Mato Grosso do Sul são registradas 17 espécies distribuídas em Stylosanthes seção Stylosanthes (12 spp.) e em Stylosanthes seção Styposanthes (5 spp.). São ocorrências inéditas para o estado: S. capitata, S. hamata, S. hippocampoides, S. humilis, S. linearifolia, S. macrocephala, S. montevidensis e $S$. nunoi.

Brandão \& Costa (1979) relataram a ocorrência de oito espécies para Mato Grosso do Sul, enquanto Dubs (1998) citou sete espécies, sendo que $S$. angustifolia Vogel (A. Krapovickas 32.867-MBM) e S. leiocarpa Vogel (G. Hatschbach 23.788-MBM) haviam sido erroneamente citadas, com base em espécimes que correspondiam a S. linearifolia.

É relevante destacar que os estudos taxonômicos anteriores (Brandão \& Costa 1979; 1982) baseavam-se sobretudo na 
morfologia do fruto. No presente trabalho observou-se que as espécies do gênero podem ser reconhecidas também pelo tamanho e revestimento dos folíolos, morfologia das inflorescências e das pétalas, além de forma, revestimento e números do(s) artículo(s) dos frutos.

Em Mato Grosso do Sul representantes de Stylosanthes ocorrem em diferentes regiões (Fig. 1) na savana (cerrado), savanaflorestada (cerradão), savana gramíneolenhosa (campo sujo) e savana-estépica florestada (chaco). Stylosanthes hamata é a única espécie que ocorre na savana-estépica florestada e $S$. linearifolia em savana florestada com afloramento rochoso.

Stylosanthes Sw., Prod.Veg. Ind. Occ. 108. 1788. Ervas perenes ou anuais, subarbustos eretos, ou prostrados, $12-150 \mathrm{~cm}$ alt.; ramo glabro, tomentoso, viloso, setoso, estrigoso; estípula externa de formas variadas, verde ou verde-avermelhada, bidentada, paleácea, de glabrescente a setosa, amplexicaule; estípula interna alva ou verde-clara, glabra ou pubescente, ápice aristado. Folha trifoliolada; folíolo subséssil, linear a largo-obovado, ápice acuminado, apiculado ou mucronado, base obtusa, cuneada, bordo inteiro, tricoma glandular geralmente ausente, raro presente $(S$. scabra, $S$. viscosa), rígidos, amarelos, base alargada, raro com pontuações ( $S$. maracajuensis), nervuras coletoras geralmente ausentes. Inflorescência de oblonga a largo-oblata, em espigas fasciculadas ou isoladas, congestas ou laxas, terminais ou axilares; bráctea externa oblonga a largoovóide, indumento variado, verde, paleácea, bidentada, venação campilódroma, paralelinérvea, ápice de formas variadas, base truncada ou amplexicaule, raro revoluta $(S$. capitata e $S$. macrocephala); bráctea interna oblonga a largo-ovóide, alva, paleácea, ápice apiculado, base revoluta; eixo plumoso quando presente, glabro a setoso; 2-3 bractéolas, lanceoladas, lineares ou ovóides, paleáceas, alvas, internamente esparso-tomentosas ou denso-tomentosas, bordo ciliado. Flores papilionadas; cálice amarelo-esverdeado, lacínios-5, gamossépalo, lacínio superior obtuso, bordo ciliado; corola amarela, amareloalaranjada ou branca; hipanto cilíndrico, glabro, amarelo-esverdeado ou vermelho-vináceo $(S$. guianensis, S. scabra, S. linearifolia); estames 10, filetes glabros, tamanhos diferenciados, cinco anteras oblongas e cinco oblatas, basifixas; ovário elíptico ou oblongo, estilete achatado, glabro, estigma cristado. Lomento, 1-2 artículos, reticulado a reticuladoareolado, glabro a denso-setoso, presença de glândulas translúcidas ( $S$. acuminata, $S$. gracilis, S. grandifolia, S. guianensis, $S$. hippocampoides, S. humilis, S. linearifolia, $S$. viscosa), presença de estilete residual, uncinado, espiralado ou encurvado; sementes oblongas a obovadas, amarelas, amarelo-ocre, amarelas pintalgadas de vermelho-vináceo, marrons ou pretas.

\section{Chave de identificação para as espécies de Stylosanthes ocorrentes em Mato Grosso do Sul}

1. Flores e frutos sustentados em sua base por um eixo rudimentar plumoso, geralmente com três bractéolas, uma externa e duas internas ( $S$. seção Styposanthes).

2. Folíolo de ápice mucronado; estípula externa de ápice caudado ou acuminado.

3. Estandarte obovado ou largo-obovado; lomento com estilete residual uncinado

1.1. S. bracteata

3'. Estandarte orbicular ou obcordado; lomento com estilete residual encurvado.

4. Bráctea externa obovada a largo-obovada ........................... 1. 2. S. capitata

4'. Bráctea externa elíptica ou largo-elíptica ......................... 1.4. S. macrocephala

2' Folíolo de ápice apiculado; estípula externa de ápice subulado.

5. Raque foliar pubescente; folíolo com nervuras inconspícuas, tricoma glandular ausente; estandarte orbicular 1.3. S. hamata 
5'. Raque foliar denso-tomentosa a setosa; folíolo com nervuras conspícuas, tricoma glandular presente; estandarte obcordado 1.5. S. scabra

1'. Flores e frutos não sustentados em sua base por um eixo rudimentar plumoso, presença de duas bractéolas internas ( $S$. seção Stylosanthes).

6. Lomento com 1 artículo.

7. Folíolos com nervuras coletoras.

8. Estilete residual encurvado; pétalas da quilha elípticas; lomento de oblongo a largo-oblongo 2.1. S. acuminata

8'. Estilete residual uncinado; pétalas da quilha falciformes; lomento elíptico.

9. Estandarte com 2 dobras na região mediana; lomento esparso-tomentoso . 2.10. S. montevidensis

9'. Estandarte com 1 dobra na região mediana; lomento glabra

2.2. S. gracilis

7'. Folíolos sem nervuras coletoras.

10. Folíolo largo-obovado a espatulado

2.8. S. longiseta

10 '. Folíolo de outras formas.

11. Lomento com segundo artículo vestigial

11'. Lomento sem artículo vestigial.

2.6. S. humilis

12. Raque foliar vilosa; asas oblongas

2.3. S. grandifolia

12'. Raque foliar tomentosa ou setosa; asas largo-obovadas.

13. Bráctea e estípula externas de ápice acuminado, estandarte largoobovado; estilete residual uncinado 2.4. S. guianensis

13'. Bráctea e estípula externas de ápice subulado; estandarte orbicular; estilete residual encurvado 2.5. S. hippocampoides

6'. Lomento com 2 artículos.

14. Inflorescência oblonga.

15. Folíolo elíptico a largo-elíptico; estípula interna oblonga

2.12. S. viscosa

15'. Folíolo linear; estípula interna ovóide a largo-ovóide 2.7. S. linearifolia

14'. Inflorescência ovóide ou elíptica.

16. Lomento glabro; estilete residual espiralado

2.11. S. nunoi

16'. Lomento esparso-tomentoso; estilete residual uncinado .... 2.9. S. maracajuensis

1. Stylosanthes seção Styposanthes Vogel, Linnaea 12: 68. 1838.

Flores sustentadas em sua base por um eixo rudimentar plumoso, geralmente com três bractéolas, uma bractéola externa e duas bractéolas internas.

1.1 Stylosanthes bracteata Vogel, Linnaea 12: 70. 1838.

Figs. 2 a-12; 1a

Erva, 12-18 cm alt., ereta; ramo densotomentoso, viloso e setoso; estípula externa ovóide ou largo-ovóide, verde, denso-tomentosa e setosa, 10-22 nervuras, 5-13 × 3-8,6 mm, ápice caudado, 2-6,5 $\mathrm{mm}$ compr.; estípula interna ovóide ou largo-ovóide a levemente triangular, alva, paleácea, externamente pubescente a esparso-tomentosa, 5-6 nervuras, 6-9 $9 \times 3-4,5 \mathrm{~mm}$ compr., ápice aristado. Folha (7-)12-23,5(-26,5) mm compr:; pecíolo geralmente denso-tomentoso, às vezes setoso, 1-3,7 mm compr.; raque foliar denso-tomentosa, 0,4-2 mm compr.; folíolo elíptico ou oblanceolado, ápice mucronado, base cuneada, obtusa, denso-viloso em ambas as superfícies, 5-13 pares de nervuras, conspícuas, nervuras coletoras ausentes, (5-) 7-19,5(-22,5) $\times 2,5-5,5 \mathrm{~mm}$. Inflorescência ovóide ou oblonga, isolada, laxa, terminal, 1(-2) espigas, 13-29 $\times$ 4,5-23 mm; bráctea externa ovóide ou largoovóide, denso-tomentosa, venação campilódroma, 8-20 nervuras, conspícuas, unifoliolada, 7-12× $5-14,5 \mathrm{~mm}$, ápice agudo, $1-2,5 \mathrm{~mm}$ compr., base levemente cordada; bráctea interna ovóide, 


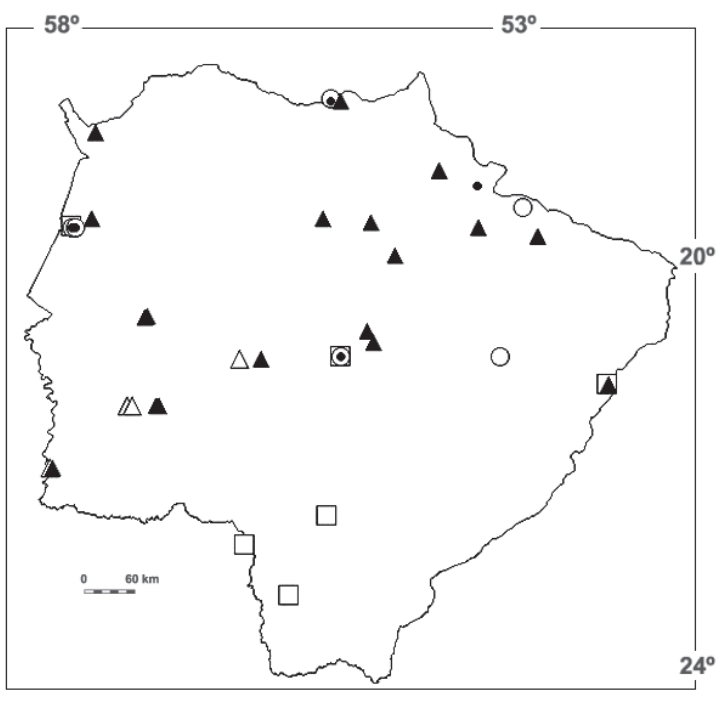

Figura 1a - Distribuição geográfica das espécies de Stylosanthes no Mato Grosso do Sul. $\square$ S. bracteata; $\bigcirc$ S. capitata; $\triangle S$. hamata $\bigcirc$ S. macrocephala; $\boldsymbol{\Delta}$. scabra.

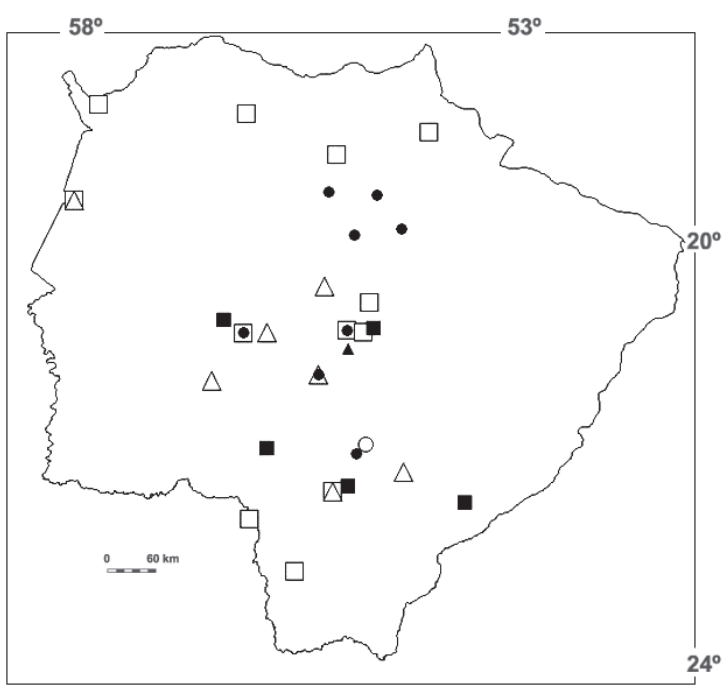

Figura 1b - Distribuição geográfica das espécies de Stylosanthes no Mato Grosso do Sul. S. acuminata; - $S$. gracilis; $\triangle$ S. grandifolia; $\bigcirc$ S. longiseta; $\Delta S$. nunoi; $\square$ S. viscosa.
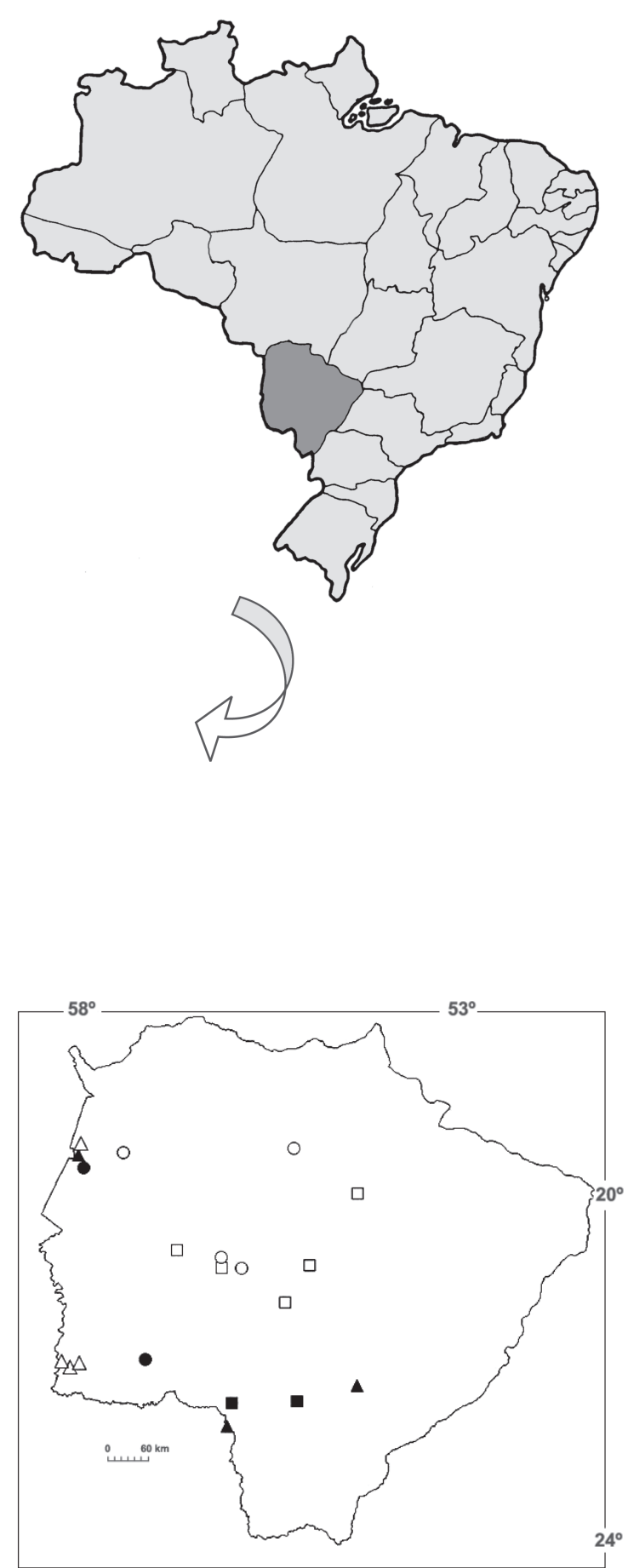

Figura 1c - Distribuição geográfica das espécies de Stylosanthes no Mato Grosso do Sul. $\square$ S. guianensis; $\Delta$ S. hippocampoides; S. humilis; $\bigcirc$ S. linearifolia; $\triangle$ S. maracajuensis; $\mathbf{D}$. montevidensis. 

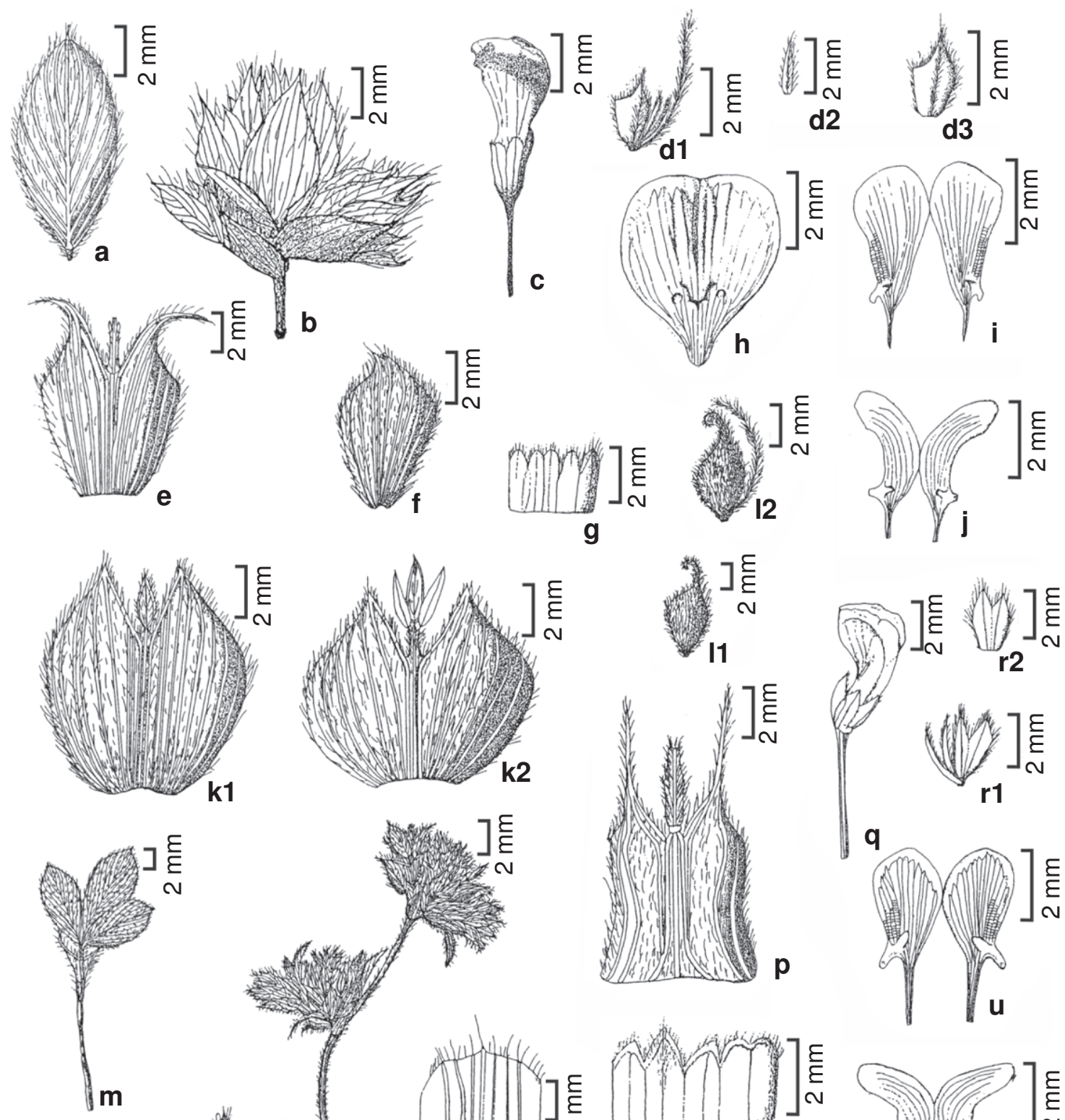

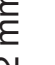

(1)
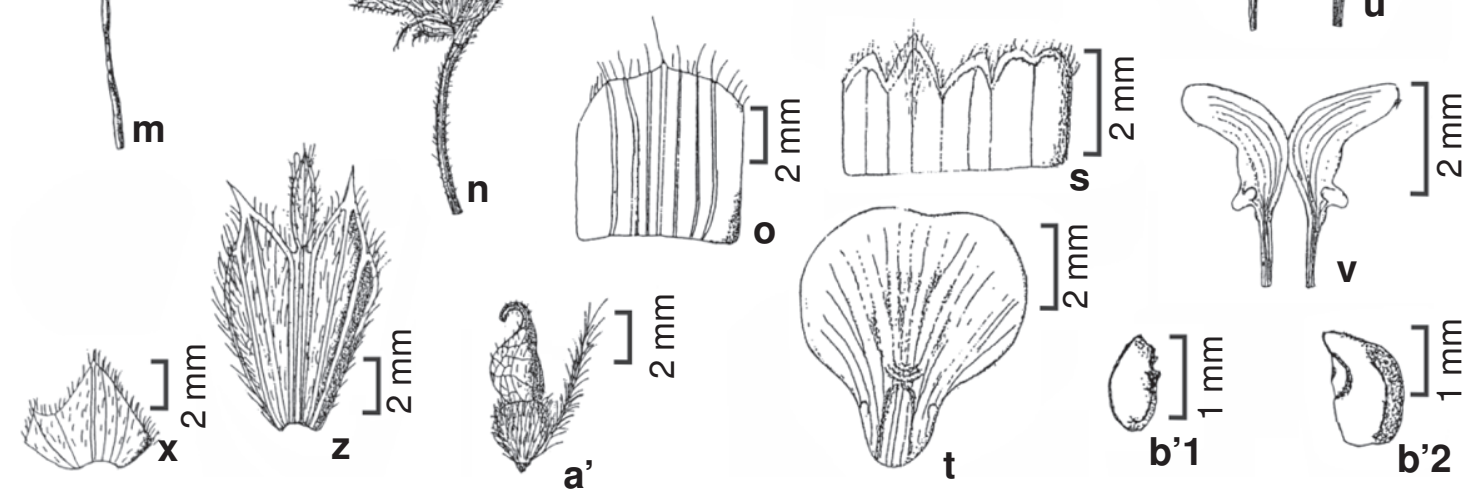

Figura 2 - a-1. Stylosanthes bracteata Vogel - a. folíolo; b. inflorescência; c. flor; d1. bractéolas e eixo rudimentar; d2. bractéola interna; d3. bractéola externa; e. estípula externa; f. estípula interna; g. cálice; h. estandarte; i. asas; j. pétalas da quilha; k1-k2. brácteas externas; 11. fruto; 12. fruto com eixo rudimentar; m-b'. S. capitata Vogel-m. folha; n. inflorescência; o. estípula interna; p. estípula externa; q. flor; r1. bractéolas; r2. bractéola externa; s. cálice; t. estandarte; u. asas; v. pétalas da quilha; x. bráctea interna; z. bráctea externa; a'. fruto com eixo rudimentar; b'1. semente do artículo inferior; b'2. semente artículo superior (a-1 Pott 7117; m-b' Costa 363). 
tomentosa, 7-14 nervuras, 5,5-6,8 × 3,6-6 mm, ápice aristado, base amplexicaule; eixo plumoso denso-setoso, 6-10 mm compr.; 1 bractéola externa ovóide, 2 internas lanceoladas ou lineares, glabras, ápice aristado. Flor 13-14 mm compr.; corola amarela; estandarte obovado ou largo-obovado, ápice obcordado, base cuneada, mácula amarelo-dourada, 1 dobra na região basal, 5-6×3-4,5 mm; asas oblongas, 2,8-3,8 $\times 2-3 \mathrm{~mm}$; pétalas da quilha falciformes, 2,53,5×1-2 mm. Lomento com 1 artículo, ovóide, denso-setoso, 3-5 × 2-3 mm compr.; estilete residual uncinado, 2,5-4 mm compr.; semente oblonga ou ovóide, amarelo-ocre ou marrom, 3-3,5 × 1-2 mm.

Material selecionado: BRASIL. MATO GROSSO DOSUL: Amambaí, 14.X.1984, fl. e fr., G. Hatschbach 48411 (MBM). Campo Grande, IX.2005, fl. e fr., $A$. Pott et al. 13.500 (HMS). Corumbá, s.d., fl., G. A. Damasceno Jr. 929 (COR). Dourados, 24.I.1979, fl., H. M. Saturnino 110 (PANG). Ponta Porã, 27.X.2004, fl. e fr., V. J. Pott \& A. Pott 7117 (HMS). Três Lagoas, 22.X.1964, fl. e fr., J. C. Gomes 2396 (SP).

Stylosanthes bracteata caracteriza-se pelo porte herbáceo, menor que $20 \mathrm{~cm}$ de altura, folíolo denso-viloso em ambas as superfícies, lomento denso-setoso, estilete residual uncinado. $S$. bracteata tende a ter menor número de espigas (1-2) e somente um artículo enquanto $S$. capitata e $S$. macrocephala espécies morfologicamente semelhantes apresentam 24 espigas e 1-2 artículos. S. bracteata assemelha-se a $S$. capitata e $S$ macrocephala pelas inflorescências isoladas, porém estas não são laxas, como na primeira espécie.

Stylosanthes bracteata ocorre em Mato Grosso, Minas Gerais, Goiás, Distrito Federal, São Paulo, Paraná (Brandão \& Costa 1979). Em Mato Grosso do Sul foi registrada nas regiões central e noroeste (Fig. 1a); em savana (cerrado), savana gramíneo-lenhosa (campo sujo). Floresce e frutifica simultaneamente de outubro a janeiro.

1.2 Stylosanthes capitata Vogel, Linnaea 12: 70. 1838

Figs. 2 m-b'; 1a

Subarbusto, $50-120 \mathrm{~cm}$ alt., ereto ou prostrado; ramo pubescente, tomentoso, setoso; estípula externa ovóide, elíptica, verde, vermelho-vináceo, denso-tomentosa, 6-18 nervuras, 6-11 × 4-8 mm, ápice acuminado, 6-10,5 mm compr.; estípula interna transversolarga, largo-oblonga, alva, paleácea, esparsotomentosa, 2-4 nervuras, 4-8,5 × 4-5,5 mm, ápice cuspidado. Folha (12-) 20-39 (-46) mm compr.; pecíolo tomentoso, 2-5 mm compr., raque foliar denso-tomentosa, 1-4 mm compr.; folíolo largo-oblongo, obovado, largo-elíptico, ápice acuminado ou mucronado, base obtusa, esparso a denso-tomentoso em ambas as superfícies, 6-12 pares de nervuras, conspícuas, nervuras coletoras ausentes, 921,5 (-34,5) × 3-6 (-10) mm. Inflorescência largo-obovada a obovada-depressa, isolada, congesta, terminal e axilar, 2-4 espigas, 10$30 \times(16-)$ 20-43 mm; bráctea externa obovada a largo-obovada, denso-tomentosa, venação campilódroma, 4-8 pares de nervuras, conspícuas, trifoliolada, 4,5-12 ×3-11,5 mm compr., ápice caudado, 2,9-4,5 mm compr., base levemente cordada; bráctea interna ovóide ou largo-ovóide, pubescente, 4-8 nervuras, 5-7,5 ×4-5 mm, ápice aristado, base revoluta; eixo plumoso denso-setoso, 3-8 mm compr.; 1 bractéola externa ovóide, 2 internas lanceoladas ou lineares, pubescentes, ápice aristado. Flor 8,5-14,5 mm compr.; corola amarela; estandarte orbicular ou obcordado, ápice obcordado, base cuneada, mácula amarelo-dourada, uma dobra na região basal, 5-6 × 3,5-5 mm; asas obovadas, 3-4 × 1,52,6 mm; pétalas da quilha falciformes, $3-4 \times$ 1-1,5 mm. Lomento com 1-2 artículos férteis, elípticos ou obovados, pubescente, tomentoso, 3,5-7 ×2-2,6 mm; estilete residual encurvado, 0,9-2 mm compr.; semente largo-oblonga, elíptica ou ovóide, amarela, amarelo-ocre, marrom ou amarela pintalgada de vermelhovináceo, 2-3 × 1-2 mm.

Material selecionado: BRASIL. MATO GROSSO DO SUL: Água Clara, 23.IV.2005, fl. e fr., A. Pott \& V. J. Pott 12821 (HMS). Campo Grande, 8.XI.2000, V. J. Pott \& A. Pott 4262 (HMS). Chapadão do Sul, 26.III.2005, fl. e fr., L. C. Costa 363 (CGMS). Corumbá, 15.IV.1972, fl. e fr., G. Hatschbach 29529 (MBM). Ladário, 5.VII.2001, fl. e fr., V. J. Pott \& A. Pott 4788 (HMS). Sonora, 3.V.1995, fl. e fr., G. Hatschbach 62183 (MBM). 
Mohlenbrock (1958), menciona que Stylosanthes capitata possui dois artículos férteis, contrariando a diagnose efetuada por Taubert (1890 apud Brandão \& Costa 1979), que cita apenas um artículo. S. capitata assemelha-se a $S$. bracteata, da qual se diferencia pela presença de 1-2 artículos versus 1 artículo na segunda espécie.

Stylosanthes capitata tem distribuição ampla no país, ocorrendo nos estados do Pará, Maranhão, Piauí, Ceará, Paraíba, Pernambuco, Bahia, Minas Gerais, Goiás e Distrito Federal (Brandão \& Costa 1979). Em Mato Grosso do Sul a espécie é de ocorrência inédita com registros nas regiões sudoeste, centro-norte, noroeste, leste e nordeste (Fig. 1a) em savana (cerrado), savana florestada (cerradão) e savana gramíneo-lenhosa (campo-sujo). Floresce e frutifica simultaneamente de novembro a julho.

1. 3 Stylosanthes hamata (L.) Taub., Verh. Bot. Vereins Prov. Brandenburg. 32(1): 22. $1890 . \quad$ Figs. 3 a-m; 1a

Subarbusto ou arbusto, $14-40 \mathrm{~cm}$. alt., raramente ereto; ramo viloso ou tomentoso; estípula externa oblonga, ovóide, verde, hialina entre as nervuras, esparso-setosa, 5-9 nervuras, 4,5-8 × 2-5 mm, ápice subulado, 3,5-5,5 mm compr.; estípula interna oblonga, verde-clara, hialina, glabra, 4-8 nervuras, 4-11,5 ×2-4 mm, ápice aristado. Folha 11-26 mm compr.; pecíolo geralmente pubescente, às vezes, esparso-setoso, 1-4 mm compr.; raque foliar pubescente, 0,9-2 mm compr.; folíolo elíptico, largo-elíptico, ápice apiculado, base obtusa, glabro ou pubescente, 4 5 pares de nervuras, inconspícuas, nervuras coletoras ausentes, 6-18 × 2,5-5,5 $\mathrm{mm}$. Inflorescência oblonga, fasciculada, congesta, terminal, $1-5$ espigas, $8-14 \times 3-8 \mathrm{~mm}$; bráctea externa ovóide, elíptica, oblonga, setosa, venação campilódroma, 6-12 nervuras, conspícuas, trifoliolada, raro unifoliolada, 4-6,5 ×2-5 mm, ápice cuspidado, 1-3,5 mm compr., base truncada, bráctea interna ovóide, glabra ou pubescente, 67 nervuras, 6,5-7,5 × 2-3 mm, ápice aristado, base revoluta; eixo plumoso, glabro ou esparsosetoso, 2,5-5 mm compr.; bractéola externa 1 , interna 2, lanceoladas ou lineares, externamente glabras, internamente denso-tomentosas, ápice aristado. Flor 8-11 mm compr.; corola amarela; estandarte orbicular, ápice obcordado, base cuneada, mácula amarelo-dourada, 2 dobras na região mediana e 1 na basal, $3,7-5 \times 3,8-5 \mathrm{~mm}$; asas obovadas, 3-3,5×1-2 $\mathrm{mm}$; pétalas da quilha falciformes, 3-3,5 × 1-1,5 mm. Lomento 1-2 artículos, geralmente um artículo vestigial, oblongo ou elíptico, glabro, setoso, 2,7-3,8 × 1,3-2,2; estilete residual encurvado, $3-7 \mathrm{~mm}$ compr.; semente oblonga, amarela, amarela pintalgada de vermelho-vináceo ou marrom, $1,5-2 \times 1-1,5 \mathrm{~mm}$. Material selecionado: BRASIL. MATO GROSSO DO SUL. Aquidauana, 4.IV.1979, fl. e fr., G. Hatschbach 60719 (MBM). Porto Murtinho, 10.XI.2002, fl. e fr., A. Pott et al. 10585 (HMS).

Stylosanthes hamata pode ser confundida com S. humilis, pois ambas possuem o estilete residual encurvado, porém, somente a primeira espécie possui eixo rudimentar plumoso na base da flor e do fruto.

Anteriormente a espécie possuía registro de ocorrência somente para o Maranhão (Brandão \& Costa 1979). Em Mato Grosso do Sul foi verificada nas regiões oeste e central (Fig. 1a); onde habita savana (cerrado), savana florestada (cerradão). Floresce e frutifica simultaneamente de abril a dezembro.

1.4 Stylosanthes macrocephala M. B. Ferreira \& Souza Costa, Soc. Bot. Brasil Anais. 28 Congr. Nac. Bot.:87. 1977.

Figs. 3 n-b'2; 1a

Subarbusto, 50-60 cm alt., ereto ou prostrado; ramo tomentoso ou setoso; estípula externa oblonga, ovóide, verde, vilosa ou tomentosa, 10-19 nervuras, 6-8 × 4-7 $\mathrm{mm}$; ápice acuminado, 4-5,5 mm compr.; estípula interna largo-oblonga ou ovóide, hialina, esparsopubescente, 4-11 nervuras, 3,5-8,5×3-5 mm, ápice aristado. Folhas (11-)16-24(-46) mm; pecíolo tomentoso, 2-6 $\mathrm{mm}$ compr., raque foliar tomentoso, 1-4 mm compr; folíolo elíptico ou oblanceolado, ápice acuminado ou mucronado, base obtusa, vilosa ou esparso-vilosa, 12-20 nervuras, conspícuas, nervuras coletoras ausentes, 8-21×4-10 mm. Inflorescência ovóide, largo-ovóide, isolada, congesta, terminal e axilar, 

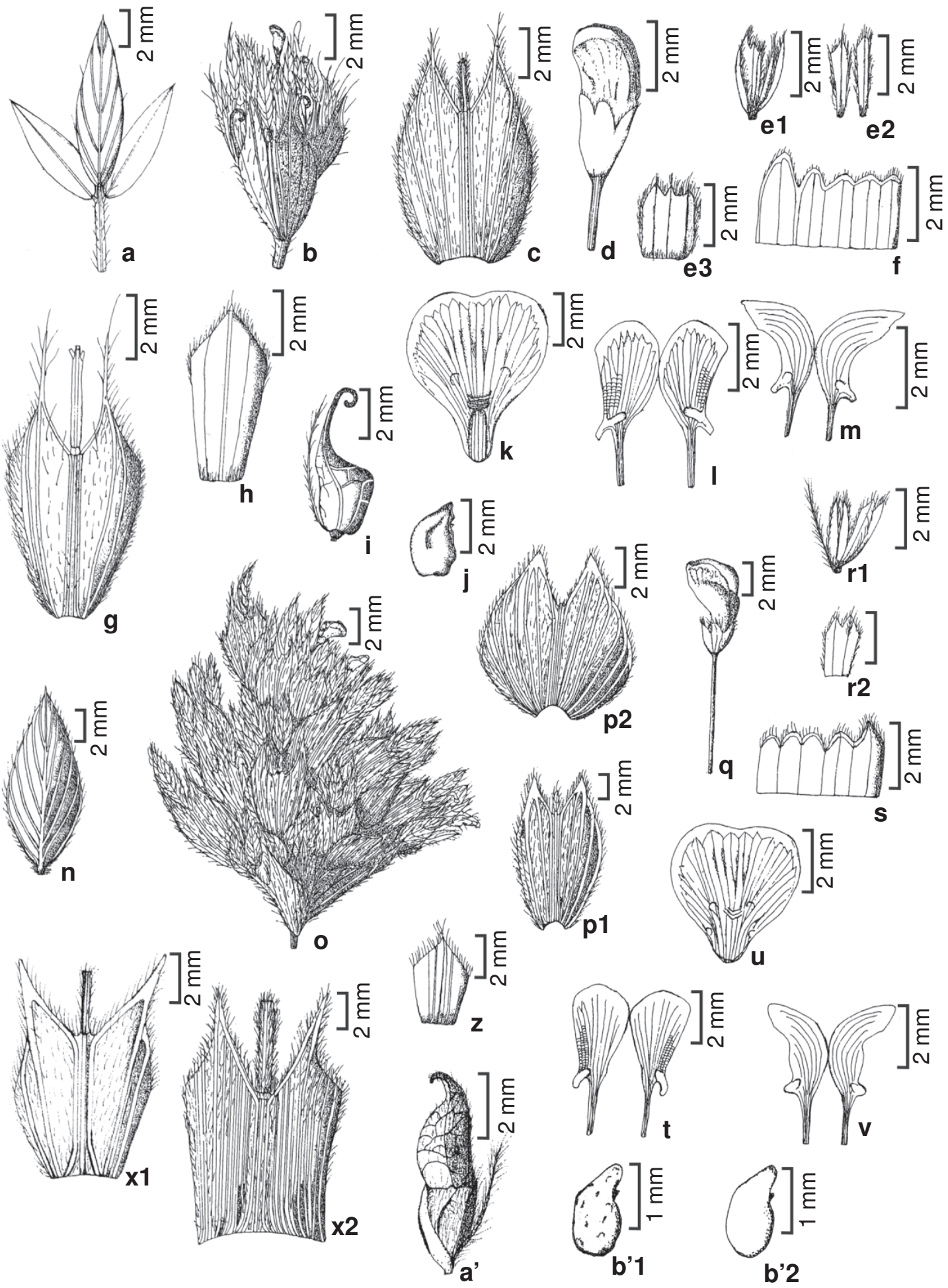
2-4 espigas, (12,5-) 18-33 × 12-31 (-42) mm; bráctea externa largo-ovóide, elíptica ou largoelíptica, tomentosa, setosa, venação campilódroma, 8-13 nervuras, conspícuas, trifoliolada, unifoliolada, 9-11×3-9,5 mm, ápice acuminado; 3-5,7mm compr., base revoulata; bráctea interna elíptica, largo-elíptica ou ovóide, pubescente, 4-8 nervuras, 4,5-7 ×3-4,5 mm, ápice aristado, base amplexicaule; eixo plumoso setoso, 3,5-8 mm compr.; bractéola externa 1, interna 2 , ovóides e lanceoladas, denso-tomentosas, ápice aristado. Flor 10-13 $\mathrm{mm}$ compr.; corola amarela; estandarte obcordado ou orbicular, ápice obcordado, base cuneada, mácula amarelo-dourado, 2 dobras na região mediana, 1 na basal, 5-5,6 $\times 4-5$ $\mathrm{mm}$; asa obovada, 3-4 $\times 2-2,6$; pétalas da quilha falciformes ou levemente oblongas, $2,5-$ 3,8 $\times 1-2 \mathrm{~mm}$. Lomento 1-2 dois artículos, oblongo, largo-ovóide, glabro ou esparsotomentoso, 5,5-6,8 $\times 2-2,5 \mathrm{~mm}$, estilete residual encurvado, 1,3-2,6 $\mathrm{mm}$ compr.; semente oblonga ou ovóide, amarela, amarelo-ocre e marrom-escura, 1,5-2,5 × 1-1,5 mm.

Material selecionado: BRASIL. MATO GROSSO DO SUL. Campo Grande, 8.XI.2000, fl. e fr., V. J. Pott \& A. Pott. 4263 (HMS). Corumbá, 12.XII.1972, fl. e fr., G. Hatschbach 29529 (MBM). Costa Rica, 11.VI.2005, fl. e fr., L. C. Costa 362 (CGMS).

Stylosanthes macrocephala aproximase morfologicamente de S. bracteata pelo tipo de inflorescência, mas difere pelo ápice da bráctea externa. S. macrocephala assemelhase também a $S$. capitata pela forma e revestimento do lomento e número dos artículos, mas difere pela bráctea externa largo-ovóide, elíptica a largo-elíptica versus obovada a largo-obovada em S. capitata.

Tem ocorrência registrada nos estados do Ceará, Bahia, Minas Gerais, Goiás, Distrito Federal (Brandão \& Costa 1979) e Mato Grosso do Sul, onde é verificada nas regiões sudoeste e noroeste, sendo de ocorrência inédita para estado (Fig. 1a); ocorre em savana (cerrado) e savana gramíneo-lenhosa (campo sujo). Floresce e frutifica simultaneamente nos meses de outubro a julho
1.5 Stylosanthes scabra Vogel, Linnaea 12: 69-70. 1838.

Figs. 4 a-n; 1a

Subarbusto, $40-150 \mathrm{~cm}$ alt., ereto; ramos glabros, vilosos, tomentosos, ou estrigosos, tricoma glandular presente; estípula externa largo-oblonga, ovóide, verde, vermelho-vinácea esverdeada, geralmente tomentosa, estrigosa, raramente esparso-tomentosa, 5-11 nervuras, 4-8 ×2-7,5 mm, ápice subulado, 1,5-5,5 mm compr.; estípula interna elíptica, ovóide, hialina, glabra, 1-6 nervuras, 5-10 $\times 2-2,5 \mathrm{~mm}$, ápice aristado. Folha 8-29 mm compr.; pecíolo tomentoso, 1-8 mm compr; raque foliar densotomentosa a setosa, 0,5-3,6 mm compr.; folíolo largo-elíptico, oblanceolado, ápice apiculado, base obtusa, pubescente, esparso-tomentoso e estrigoso na região da nervura central, presença de tricomas glandulares, 4-6 pares de nervuras, conspícuas, nervuras coletoras ausentes, 5-19 × 2-7 mm. Inflorescência oblongas, elípticas e largo-elípticas, fasciculada, congesta, terminais e axilares, 1-2 espigas, 1024×3-16 mm; bráctea externa elíptica, largoelíptica, tomentosa, estrigosa, venação campilódroma, 5-13 nervuras, conspícuas, trifoliolada, unifoliolada, 4-6×2-6 mm, ápice cuspidado, 1,8-3 $\mathrm{mm}$ compr., base amplexicaule; bráctea interna elíptica ou ovóide, glabra, 3-5 nervuras, 4-7 ×2-3,5 mm, ápice aristado, base amplexicaule; eixo plumoso, esparso-tomentoso ou glabro, 2,5-7 $\mathrm{mm}$ compr.; bractéola externa 1, interna 2 , lanceoladas, lineares, glabra, ápice aristado. Flor 8-9,5 mm compr.; corola amarela; estandarte obcordado, ápice obcordado, base cuneada, mácula vermelho-vináceas; 2 dobras na região mediana 1 na basal, 3-5 ×3,5-4 mm; asa obovada, espatulada, 3-3,5 × 1-2 mm; pétalas da quilha falciformes, $2,5-3 \times 1-2 \mathrm{~mm}$. Lomento com 2 artículos férteis, obovado ou elíptico, esparso a denso-setoso, 3-7×1-3 mm; estilete residual encurvado, $1-2,5 \mathrm{~mm}$ compr.; semente largo-elíptica ou largo-oblonga, amarela, amarelo-ocre ou preta, 1-2,5 $\times 1-2 \mathrm{~mm}$. Material selecionado: BRASIL MATO GROSSODO SUL.Alcinópolis, 18.X.2002, fl. e fr., A. Pott et al. 10365 (HMS); Aquidauana, 29.I.1979, est., M. B. Ferreira 10427(MBM, PANG); Bonito, 19.VII.2006, fl. efr., L. C. 

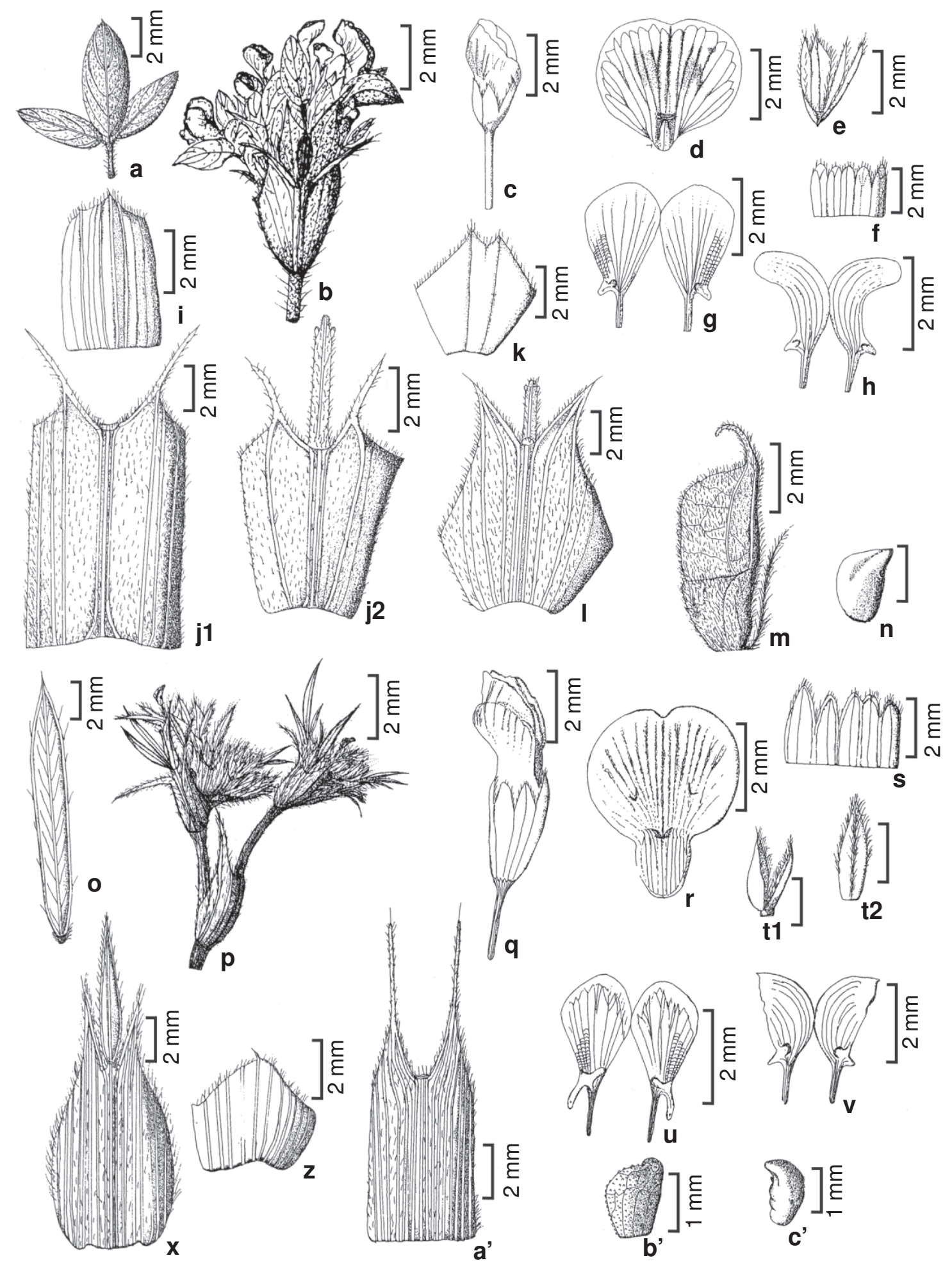

Figura 4 - a-n. Stylosanthes scabra Vogel - a. folha; b. inflorescência; c. flor; d. estandarte; e. bractéolas; f. cálice; g. asas; h. pétalas da quilha; i. estípula interna; 1 - j2. estípulas externas; $k$. bráctea interna; 1 . bráctea externa; $\mathrm{m}$. fruto com eixo rudimentar; n. semente; o-c'. S. acuminata M. B. Ferreira \& Souza Costa-o. folíolo; p. inflorescência; q. flor; r. estandarte; s. cálice; t1 bractéolas; $\mathrm{t} 2$. bractéola; u. asas; v. pétalas da quilha; $x$. bráctea externa; $z$. bráctea interna; a'. estípula externa; b'. fruto; c'. semente (a-n Costa 360; o-c' Pott 9583) 
Costa 382 (CGMS); Campo Grande, 23.XII.1932, fl., J. Otero \& F. C. Hoehne 30648 (SP); Camapuã, 27.II.2002, fl. fr, A. Pott et al. 9542 (HMS); Chapadão do Sul, 1.V.2005, fl. e fr., L. C. Costa 357(CGMS, HMS); Costa Rica, 6.VI.2005, fl. e fr., L. C. Costa 360 (CGMS); Jaraguari, 5.III.2004, fl. e fr., A Pott et al. 11489 (HMS); Corumbá, 30.II.2003, fl. e fr., A. Pott \& V. J. Pott 10976 (HMS); Miranda, 19.XI.2002, fl. e fr., A. Pott et al. 10864 (HMS); Navirai, 18.IV.2005, fl. fr., A. Pott et al. 12775 (HMS); Nova Andradina, 8.VIII.1997, fl. e fr., $G$. Hatschbach 66549 (MBM, PANG); Nioaque, 2.IV.2001, fl. e fr., A. Pott et al. 8781 (HMS); Piraputanga, 2.IV.2006, fl. fr, L. C. Costa 378 (CGMS, HMS); Rio Verde de Mato Grosso, 27.VII.1973, fl. e fr., G. Hatschbach 32426(MBM, PANG); São Gabriel d' Oeste, 15.VI.2002, fl. e fr., A. Pott et al. 10050 (HMS); Três Lagoas, 19.X.1964, fl. fr., J. C. Gomes 2346 (SP).

Stylosanthes scabra pode ser confundida com $S$. viscosa pelos tricomas glandulares que recobrem ramos e folíolos. Porém, S. scabra possui estilete residual encurvado e eixo rudimentar plumoso enquanto em $S$. viscosa o estilete é espiralado e o eixo ausente.

A espécie ocorre na Bahia, Minas Gerais, Goiás, Mato Grosso e São Paulo (Brandão \& Costa 1979) e em Mato Grosso do Sul nas regiões centro-norte, sudoeste, nordeste, noroeste e norte (Fig. 1a). Geralmente verifica-se a ocorrência de $S$. scabra associada a $S$. acuminata e $S$. grandifolia. Pode ser encontrada em savana (cerrado), savana florestada (cerradão) e savana gramíneo-lenhosa. (campo sujo). Floresce e frutifica simultaneamente de outubro a agosto.

2. Stylosanthes seção Stylosanthes. Seção Eustylosanthes Vogel, Linnaea 12:63. 1838. Seção Astyposanthes Hert., Rev. Sudamer. Bot. 7: 209. 1943. Seção Astyposanthes (Hert.) Mohlenbrock, Ann. Missouri Bot. Gard. 44: 327. 1958.

Flores não sustentadas em sua base por um eixo rudimentar plumoso, presença de duas bractéolas internas.

2.1 Stylosanthes acuminata M. B. Ferreira $\&$ Souza Costa, Soc. Bot. Brasil Anais. 28 Congr. Nac. Bot.: 80. 1977.

Figs. 4 o-c'; 1b

Subarbusto, 40-90 cm alt, ereto; ramos vilosos ou tomentosos; estípula externa, oblonga, obovada, verde, geralmente denso-tomentosa ou setosa, raramente pubescente, 6-17 nervuras, 6$10 \times 5-8 \mathrm{~mm}$, ápice subulado, 6-13 mm compr.; estípula interna oblonga, verde-clara, glabra, 814 nervuras, (5,5-) 8-12,5×2,6-5,5 mm, ápice aristado. Folha (25-) 30-41 (-51) mm compr.; pecíolo geralmente denso-tomentoso ou setoso, raramente pubescente, $2-5 \mathrm{~mm}$ compr.; raque foliar denso-tomentosa e setosa, 1-2,5 mm compr.; folíolo lanceolado, oblanceolado, ápice acuminado, base atenuada, geralmente pubescente ou esparso-tomentoso, raramente glabro, 5-11 pares de nervuras, inconspícuas, nervuras coletoras presentes, alvas (16-) 23$33 \times 2,4-7 \mathrm{~mm}$. Inflorescência oblonga, ovóide a largo-ovóide, fasciculada, congesta, terminal e axilar, $1-5$ espigas, $(7-) 14,5-24(-34,6) \times(5-)$ 11-17(-28) $\mathrm{mm}$; bráctea externa oblonga, obovada ou elíptica, externamente pubescente a tomentosa, internamente denso-tomentosa sobre as nervuras centrais, venação crapedódroma, 12-18 nervuras, conspícuas, trifoliolada, 4,5-11 $\times 3-7 \mathrm{~mm}$, ápice caudado, 1,5-3,5 mm compr., base truncada; bráctea interna ovóide, glabra, 8-12 nervuras, 6-10×3-5 mm, ápice aristado, base truncada; 2 bractéolas, lanceoladas, pubescentes, ápice aristado, 3-5 ×0,4-1 mm. Flor 9-13 mm compr.; corola amarela; estandarte obovado, largo-obovado ou obcordado, ápice obcordado, base obtusa, mácula vermelhovináceo, 1 dobra na região basal, 2 na região mediana, 4-6×4-5,6 mm; asas obovadas, 3-5 $\times 2-3 \mathrm{~mm}$; pétalas da quilha elípticas, ligeiramente falciformes, 3-4×1-0,2 $\mathrm{mm}$. Lomento 1 artículo, oblongo, largo-oblongo, glabro, 2,5-3,5 × 1,62,5; estilete residual encurvado, $0,2-0,4 \mathrm{~mm}$ compr.; semente largo-oblonga, ovóide, amarela, amarela pintalgada de marrom-avermelhado, marrom-escura ou preta, 1-3 $\times 1-2,5 \mathrm{~mm}$.

Material examinado: BRASIL. MATO GROSSODO SUL: Alcinópolis, 2.III.2002, fl. e fr., A. Pott et al. 9583(HMS).Amambai, 14.II.1983, fl. efr., G. Hatschbach 46221 (MBM, PANG); Aquidauana, fl. fr., A. Pott et al. 13889 (HMS); Campo Grande, 3.V.2005, fl. e fr., $L$. C. Costa 354 (CGMS); Corumbá, fr., D. F. R. Bommer 45 (SP); Coxim, 3.V.1995, fl. efr., G. Hatschbach 62157 (MBM); Dourados, 31.I.1979, fl. e fr., M. B. Ferreira 7740 (PANG); Jaraguari, fl. e fr., A. Pott et al. 11476 (HMS); Pacari, 12.XII.1982, fl. e fr., G. Hatschbach 
45930 (MBM, PANG); Ponta Porã, 24.I.1979, est., H. M. Saturnino 112 (PANG); Nioaque, 23.II.2006, fl. fr., A. Pott et al. 14050 (HMS).

Stylosanthes acuminata é facilmente identificada pelos folíolos lanceolados ou oblanceolados de ápice acuminado.

Espécie encontrada na Bahia, Minas Gerais, São Paulo Distrito Federal, Mato Grosso, Paraná (Brandão \& Costa 1979) e em Mato Grosso do Sul, onde ocorre nas regiões centro-norte, norte, noroeste, sudoeste e leste (Fig. 1b), em savana florestada (cerradão) e savana gramíneo-lenhosa (campo sujo). Ocorre geralmente associada a $S$. guianensis, S. scabra e $S$. viscosa, o que também foi observado por Brandão \& Costa (1979). Floresce e frutifica de dezembro a maio.

2.2 Stylosanthes gracilis Kunth, Nov. Gen. Sp. (quarto ed.). 6: 507-508. 1823 [1824].

Figs. 5 a-m; $1 \mathrm{c}$

Subarbusto ou arbusto, 90-150 cm alt., ereto; ramos vilosos ou tomentosos; estípula externa oblonga ou ovóide, verde, pubescente e setosa, 11-22 nervuras, 5-16 × 3,5-9 mm, ápice acuminado, 2-7,5 mm compr.; estípulas internas oblongas ou ovóides, hialinas, glabras ou pubescentes, 10-18 nervuras, 6-8 × 3,24,8 , ápice aristado. Folha (13-) 19-52 (-62,5) mm compr.; pecíolo glabro, (2-) 5-12 mm compr.; raque foliar glabra, 1-3 mm compr.; folíolo linear, lanceolado, ápice apiculado, base atenuada, glabro ou pubescente, 2-3 pares de nervuras, inconspícuas, nervuras coletoras presentes, (10-) 15-31 (-47) × 1,5-4 mm. Inflorescência oblonga, ovóide, largo-ovóide, isolada, congesta, terminal, 1-5 espigas, 10$27 \times 4-25(-31) \mathrm{mm}$; bráctea externa ovóide, elíptica e oblonga, setosa, denso-setosa, venação paralelinérvea, 12-16 nervuras, conspícuas, unifoliolada, 5-10×3-6 mm, ápice acuminado, 1-5,5 mm, base amplexicaule; bráctea interna ovóide, elíptica, glabra ou pubescente, 8-14 nervuras, 5-7 × 3-6 mm, ápice aristado, base amplexicaule; 2 bractéolas, lineares ou lanceoladas, internamente densotomentosas, ápice aristado. Flor 10-2 mm compr.; corola amarela; estandarte obcordado, ápice obcordado, base cuneada, mácula vermelho-vinácea, 2 dobras na região mediana, 6-7 ×3-3,5 mm; asas obovadas, 3-4 × 1,3-2,5 $\mathrm{mm}$; pétalas da quilha falciformes, 2,6-3,9×1,2$1,6 \mathrm{~mm}$. Lomento com 1 artículo, elíptico, glabro, 2,7-3,5 ×2-2,9; estilete residual uncinado, 0,4$0,8 \mathrm{~mm}$ compr.; semente oblonga ou elíptica, preta, marrom-escura, 2-3 × 1,2-2 mm.

Material selecionado: BRASIL. MATO GROSSO DO SUL: Aquidauana, 29. I.1979, est., M. B. Ferreira 10426 (PANG); Camapuã, 27.II.2002, fl. e fr., A. Pott et al. 9543 (HMS); Campo Grande, 29.I.1979, fr., $M$. B. Ferreira 104422, (PANG); Rio Verde de Mato Grosso, 28.VIII.1973, fl. fr., G. Hatschbach 32444 (MBM); Rio Brilhante 26.IV.1984, est., J. F. M. Valls et. al. 7714 (RB); São Gabriel d' Oeste, 15.VI.2002, fl. e fr., A. Pott et. al. 10047 (HMS); Sidrolândia, 12.IX.2001, fr., A. Sciamarelli et al. 971 (DDMS).

Stylosanthes gracilis é facilmente identificada pela presença de folíolos lineares ou lanceolados de ápice apiculado.

Além de Mato Grosso do Sul esta espécie de ampla distribuição é encontrada em Roraima, Pará, Acre, Piauí Ceará, Rio Grande do Norte, Paraíba, Pernambuco, Bahia, Rio de Janeiro, São Paulo, Minas Gerais, Goiás, Distrito Federal e Mato Grosso (Brandão \& Costa 1979). Em Mato Grosso do Sul ocorre nas regiões central, sul, norte, nordeste (Fig. 1c), em savana (cerrado) e savana florestada (cerradão). Floresce e frutifica de janeiro a setembro.

2.3 Stylosanthes grandifolia M. B. Ferreira \& Souza Costa, Soc. Bot. Brasil Anais. 28 (Cong. 77): 102. 1977. Figs. 5 n-b'; $1 \mathrm{~b}$

Subarbusto, 70-110 cm alt., ereto; ramo viloso, setoso ou tomentoso; estípula externa oblonga, verde, geralmente vilosa e setosa, 8-16 nervuras, 9-17 × 3-9 mm, ápice subulado, 410,5 mm compr.; estípula interna oblonga, alva, paleácea, glabra ou pubescente, 8-12 nervuras, 5-13 × 2,5-6 mm, ápice aristado. Folha (21-) 29-45 (-60) mm compr.; pecíolo viloso e setoso, (3,5-) 6-15 mm compr.; raque foliar vilosa, 0,8$3 \mathrm{~mm}$ compr.; folíolo oblanceolado, ápice mucronado, base obtusa, glabro ou pubescente, 4-10 pares de nervuras, inconspícuas, nervuras coletoras ausentes, (13-) 30-40,5 (-47) ×3-10,5 


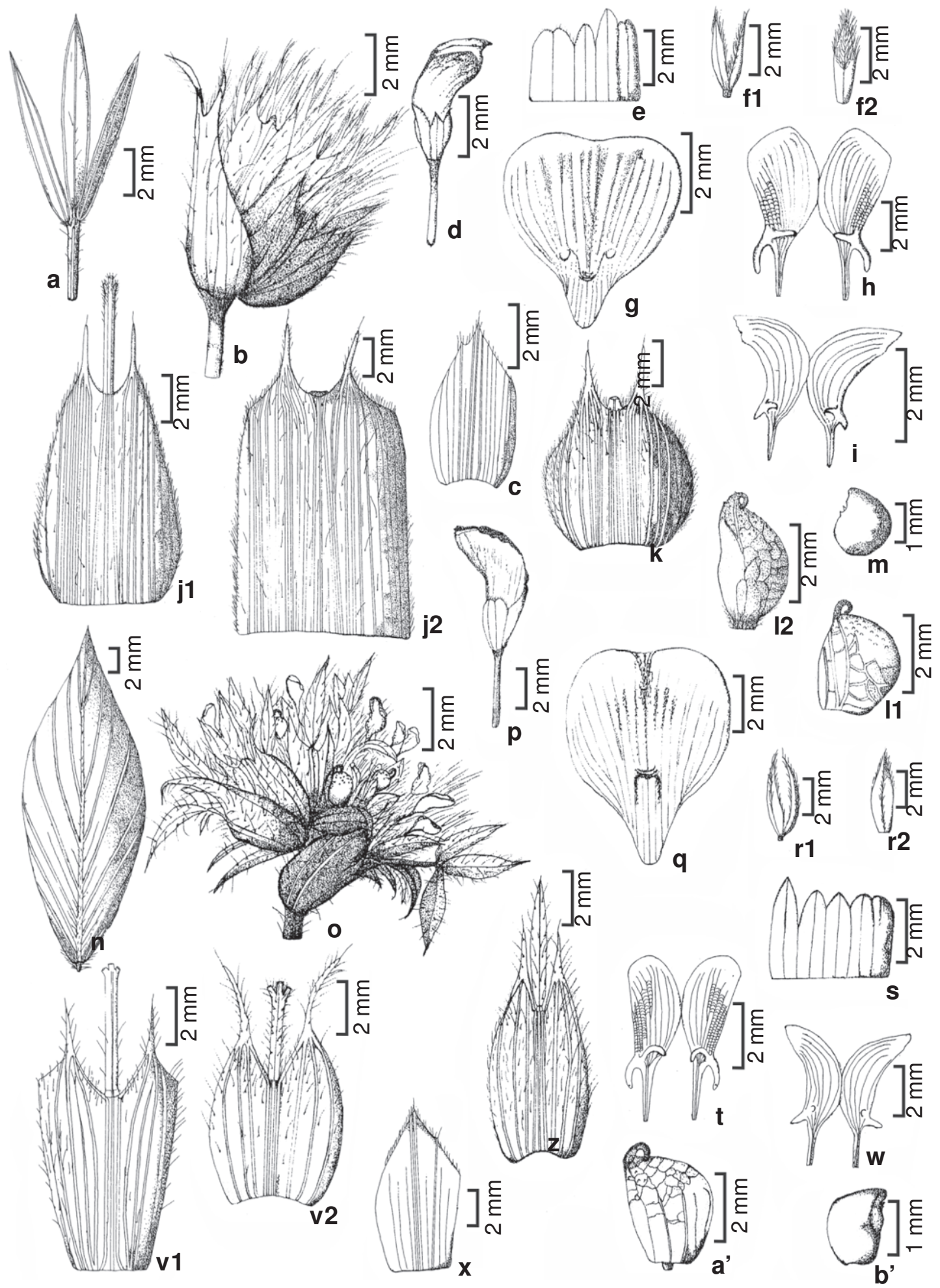

Figura 5 - a-m. Stylosanthes gracilis Sw. - a. folha; b. inflorescência; c. estípula interna;.d. flor; e. cálice; f1. bractéolas; f 2. bractéola; g. estandarte; h. asa; i. pétalas da quilha; j1-j2. estipula externa; k. bráctea; 11-12. fruto; m. semente; n-b'. S. grandifolia M. B. Ferreira \& Souza Costa -n. folíolo; o. inflorescência; p flor; q. Estandarte; r1 bractéolas; r2. bractéola; s. Cálice; t. asa. u. pétalas da quilha; v1-v2. estípula externa; x. Estípula interna; z. Bráctea externa; a' fruto; b'. semente (a-m Pott 10047; n-b' Costa 375). 
(-14) mm. Inflorescência ovóides, largo-ovóides, oblatas ou circulares, isolada, congesta, terminal, 1-8 espigas, (7-)12-25 (-28) × 11-28 (-32,9) $\mathrm{mm}$; bráctea externa oblonga, obovada ou elíptica, vilosa, setosa, venação paralelinérvea, 4-9 pares de nervuras, conspícuas, trifoliolada, 6-16,5 ($20,5) \times 2-7(-8,5) \mathrm{mm}$, ápice subulado, $2-3,5 \mathrm{~mm}$ compr., base amplexicaule; bráctea interna ovóide, glabra a pubescente, 8-12 nervuras, 5-7 $\times 2-5 \mathrm{~mm}$, ápice aristado, base amplexicaule; 2 bractéolas lanceoladas, pubescentes, ápice aristado, 3,5-5 × 0,6-1,5 mm. Flor 10-13 mm compr.; corola amarela; estandarte obovado ou obcordado, ápice arredondado ou obcordado, base cuneada, mácula amarela, 2 dobras na região mediana, 1 basal, 5,5-9 ×3,5-6 mm; asa oblonga, 4-6,5 $\times 2-2,5 \mathrm{~mm}$; pétalas da quilha oblongas, levemente falciformes, 4-5×1-2 mm. Lomento com 1 artículo, largo-elíptico, glabro ou pubescente, com glândulas no ápice do artículo, 3-4 × 2-3 $\mathrm{mm}$; estilete residual uncinado, $0,4-0,7 \mathrm{~mm}$ compr.; semente elíptica, oblonga ou largooblonga, preta, marrom-escura ou amarela, 2-3 $\times 1,4-2,3 \mathrm{~mm}$.

Material selecionado: BRASIL. MATO GROSSO DO SUL. Campo Grande, 2.X.2006, fl. e fr., $L$. C. Costa 392 (CGMS); Caracol, 10.II.1993, fl. e fr., $G$. Hatschbach 56846 (MBM); Dourados, 24.I.1979, est., H. Saturnino 115 (PANG); Miranda, 31.I.1979, fl. e fr., N. M. Costa \& M. B. Ferreira 7708 (PANG); Rochedo 25.I.1979, fl. e fr., E. C. Tenório s.n. (RB-363.851); Sidrolândia, 23.I.1971, fl. e fr., $G$. Hatschbach 26036 (MBM); Terenos, 31.I.1979, fl. e fr., A. Krapovickas \& C. L. Cristobal s.n. (PANG-9159).

Stylosanthes grandifolia é prontamente identificada pela inflorescência de formato ovóide a circular, isolada. Aproxima-se morfologicamente de $S$. acuminata, $S$. gracilis e $S$. guianensis pelo número de artículos do lomento, mas difere pelos folíolos oblanceolados, com nervuras inconspícuas.

Ocorrência anteriormente conhecida apenas em Minas Gerais (Brandão \& Costa, 1979). Em Mato Grosso do Sul ocorre nas regiões central, noroeste, sul e sudeste (Fig. 1b) em savana (cerrado) e savana florestada. Floresce e frutifica de dezembro a fevereiro.
2.4 Stylosanthes guianensis (Aubl.) Sw., Kongl. Vetensk. Acad. Nya Handl. 11: 296.1789.

Figs. 6 a-n; 1c

Subarbusto, 40-60 cm alt., prostrado; ramo tomentoso, setoso, raro glabrescente; estípula externa oblonga, obovada ou estreita-elíptica, verde, geralmente tomentosa e setosa, 10-22 nervuras, 5-14 × 2-5 mm, ápice acuminado, 26,5 mm compr.; estípula interna ovóide, alva, paleácea, pubescente, 3-10 nervuras, 4,5-10 $\times$ $2-6,5 \mathrm{~mm}$, ápice aristado. Folha (14,5-) $19-43 \mathrm{~mm}$ compr.; pecíolo tomentoso, $2-8 \mathrm{~mm}$ compr.; raque foliar geralmente tomentosa, raro setosa, $1-2 \mathrm{~mm}$ compr:; folíolo elíptico, lanceolado ou oblanceolado, ápice apiculado ou mucronado, base obtusa, tomentoso, 4-10 pares de nervuras, conspícuas, nervuras coletoras ausentes, $15,5-27 \times 1-4 \mathrm{~mm}$. Inflorescência ovóide, largo-ovóide, fasciculada, congesta, terminal e axilar, 2-4 espigas, 7-24,5× 5-18 (-26,5) mm; bráctea externa elíptica, ovóide ou oblonga, setosa, venação paralelinérvea, 5-12 nervuras, conspícuas, trifoliolada, raro unifoliolada, 3,5-6 × 2-6 mm, ápice acuminado, 0,7-4 mm compr., base truncada; bráctea interna elíptica, ovóide ou largo-ovóide, $1-5$ nervuras, 3,-6,5×2$4,5 \mathrm{~mm}$, ápice aristado, base truncada, 2 bractéolas, lanceoladas ou lineares, glabras, ápice aristado. Flor 8-13 mm compr.; corola amarela ou branca; estandarte largo-obovado, ápice obcordado, base cuneada, mácula vermelho-vinácea, 2 dobras na região mediana e 1 basal, 4-6,6×3-5,8 mm; asas largo-obovadas, 3-6×1,5-3 mm; pétalas da quilha falciformes, $2,5-3 \times 1-1,6 \mathrm{~mm}$. Lomento com 1 artículo, largo-elíptico, glabro, 3-3,8×1,8-2,3 mm, estilete uncinado, 0,4-0,7 mm compr.; semente elíptica, preta, 1,6-2,7×0,9-2 mm.

Material selecionado: BRASIL. MATO GROSSO DO SUL: Aquidauana, IX.2005, fl. e fr., A. Pott \& V. J. Pott 13486 (HMS); Bonito, 19.VIII.2006, fl. e fr., L. C. Costa 384 (CGMS,HMS); Bela Vista, 19.IV.2005, fl. e fr., A. Pott \& V. J. Pott 12794 (HMS); Camapuã, 27.II.2002, fl. e fr., A. Pott et. al. 9541 (HMS); Campo Grande 2.X.2006, fl. e fr., L. C. Costa 392 (CGMS,HMS); Chapadão do Sul, 9.IV.2004, fl. e fr., A. Pott et al. 11747 (HMS); Corumbá, 7.V.2003, fl. e fr., V. Pott et. al. 6235 (HMS).

Morfologicamete, S. guianensis aproximase de $S$. acuminata, $S$. gracilis e $S$. grandifolia, devido à presença de um artículo no fruto. $S$. 


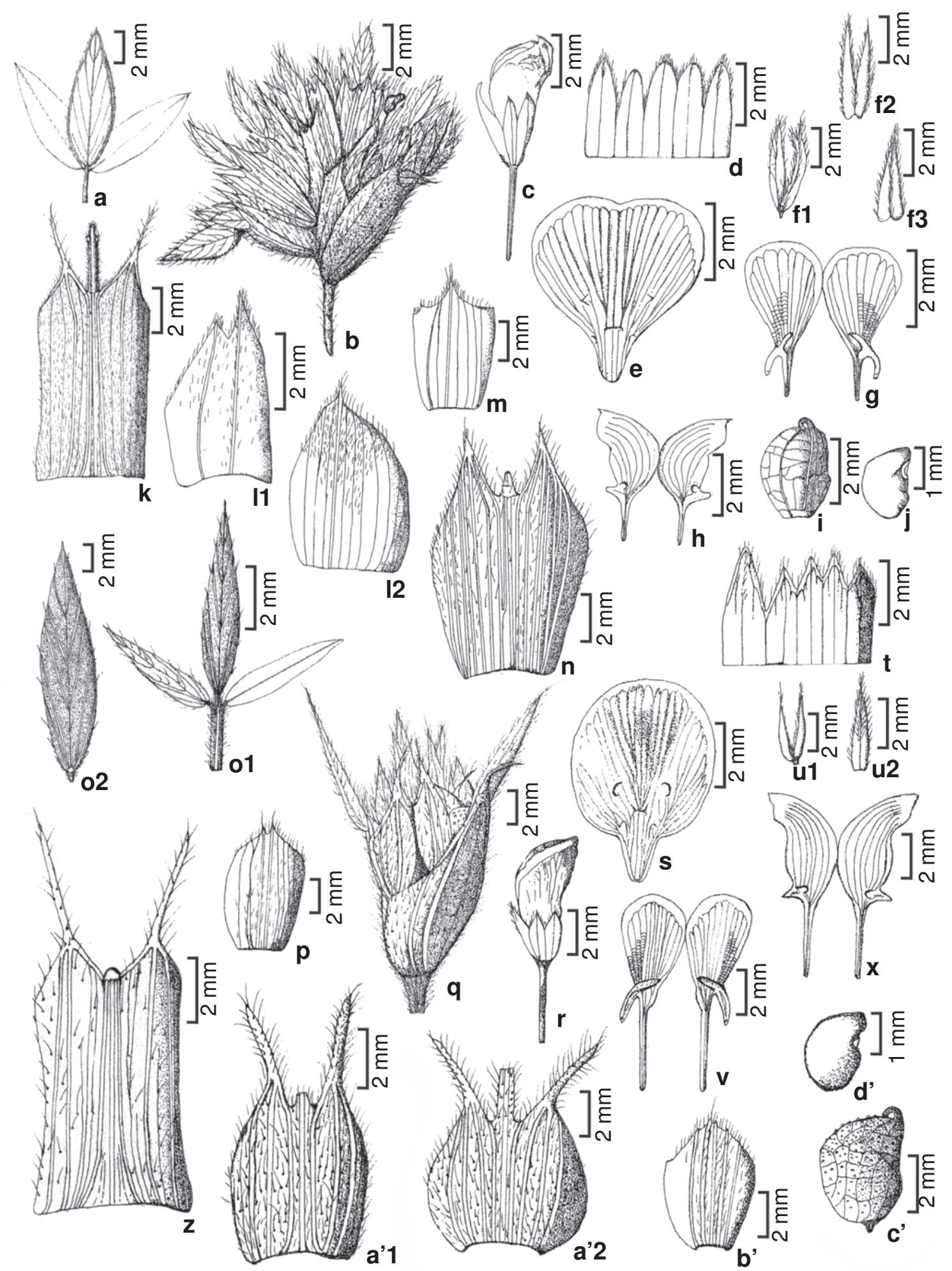

Figura 6 - a-n. Stylosanthes guianensis (Aubl) Sw. a. folha; b. inflorescência; c. flor; d. dálice; e. estandarte; f1. bractéolas; f2-f3. bractéola; g. asas; h. pétalas da quilha; i. fruto; j. semente; k. estípula externa; 11-12. estípula interna; m. bráctea interna; n. bráctea externa. o-d' Stylosanthes hippocampoides Mohlenbr. o1-o2. folha; p. estípula interna; q. inflorescência; r. flor; s. estandarte; t.cálice; u1. bractéolas; u2. bractéola; v. asas; x. pétalas da quilha; z. estípula externa; a'1-a'2. bráctea externa; b'. bráctea interna; c'. fruto; d'. semente. (a-n. Costa 392; o-d': Pott 7469) 
guianensis difere de $S$. acuminata e de $S$. gracilis pela ausência de nervuras coletoras no bordo foliar e de $S$. grandifolia pelo hábito arbustivo prostrado.

Ocorrência da espécie é registrada no Pará, Maranhão, Ceará, Paraíba, Pernambuco, Bahia, Minas Gerais, Goiás, Distrito Federal, Mato Grosso, Rio de Janeiro, São Paulo e Paraná (Brandão \& Costa 1979). Em Mato Grosso do Sul ocorre nas regiões central, norte, nordeste, noroeste, sul e sudeste (Fig. 1c), em savana (cerrado), savana florestada (cerradão) e savana gramíneo-lenhosa (campo-sujo). Flores e frutos registrados para todos os meses do ano.

2.5 Stylosanthes hippocampoides Mohlenbr., Ann. Missouri Bot. Gard. 44(4): 339. 1957 [1958].

Figs. 6 o-d'; $1 \mathrm{~b}$

Subarbusto, 40-60 cm alt., ereto; ramo glabrescente, geralmente denso-tomentoso, algumas vezes setosos; estípula externa oblonga e elíptica, verde, geralmente tomentosa a setoso, 7 11 nervuras, 6,6-8,5 ×2-5 mm, ápice subulado, caudado, 5-10,2 mm compr.; estípula interna oblonga, verde-clara, paleácea, glabro, 3-5 nervuras 5,5-8 $\times 2-3,5 \mathrm{~mm}$, ápice aristado. Folha 20,5-33 (-41) mm compr.; pecíolo geralmente tomentoso, algumas vezes setoso, 4-8 mm compr.; raque foliar geralmente tomentosa, a setosa, 0,8 1,5 mm compr., folíolo lanceolado, ápice apiculado ou mucronado, base obtusa, esparso-setoso, 4-6 pares de nervuras, conspícuas, nervuras coletoras ausentes, 15,5-27×14 mm. Inflorescência ovóide, largo-ovóide, fasciculada, congesta, terminal, axilar, 2-6 espigas, $10-19,5 \times 8-13(-21,5) \mathrm{mm}$; bráctea externa elíptica a largo-elíptica, geralmente setosa, algumas vezes denso-setosa, venação paralelinérvea, 7-12 nervuras, conspícuas, unifoliolada, 3,5-8 $\times 2,4-5 \mathrm{~mm}$, ápice subulado, 2-7 mm compr., base amplexicaule; bráctea interna elíptica, largo-elíptica, esparso-setoso, 1-3 nervuras, 3-6 × 2-4,5 mm, ápice aristado, base amplexicaule; 2 bractéolas lanceoladas ou lineares, internamente glabras, externamente tomentosas, ápice aristado. Flor 10-12 mm compr.; corola amarela; estandarte orbicular, ápice obcordado, base cuneada, mácula vermelho-vinácea, 1 dobra na região basal, 5,7-8,6 $\times 4-5,8 \mathrm{~mm}$; asas largo- obovadas, 4-5 × 1,5-2,5 mm; pétalas da quilha falciformes, 3,8-4×1-1,6 mm. Lomento 1 artículo, largo-elíptico, glabro, glândulas translúcidas presentes, 3-6 × 1,8-3 mm; estilete residual encurvado, $0,5-0,7 \mathrm{~mm}$ compr.; semente largoovóide e largo-elíptica, amarelo-ocre, marromescura ou preta, 1,5-2,7 ×1,5-2 mm.

Material selecionado: BRASIL. MATO GROSSO DO SUL. Caracol, 10.II.1993, fl. fr., G. Hatschbach 58855 (MBM). Corumbá, 19.II.2005, fl. fr., V. J. Pott et al. 7469 (HMS). Ponta Porã, 12.II.1983, fl. fr., $G$. Hatschbach 46140 (PANG).

Stylosanthes hippocampoides pode ser identificada pelas nervuras conspícuas e paralelas tanto nos folíolos como nas brácteas, inflorescência de formato ovóide a largoovóide, fasciculada e congesta e estandarte com mácula vermelho-vináceo.

Tem ocorrência registrada na Bahia, Goiás, Mato Grosso, Rio de Janeiro, São Paulo, Paraná e Santa Catarina (Brandão \& Costa 1979). Neste estudo, S. hippocampoides foi encontrada nas regiões sudeste e noroeste, sendo sua ocorrência inédita para o estado (Fig. 1b), ocorrendo em savana (cerrado), savana gramíneo-lenhosa (campo-sujo). Flores e frutos observados de dezembro a março.

2.6 Stylosanthes humilis Kunth, Nov. Gen. Sp. (quarto ed.). 6: 506.1823. Figs. 7 a-m2; 1b

Subarbusto, 20-30 cm alt., prostrado; ramo geralmente setosos, algumas vezes tomentosos; estípula externa oblonga ou elíptica, verde, geralmente tomentosa, algumas vezes setosa, 3-7 nervuras, 4-9 × 2-5 mm, ápice acuminado, 2-3 mm compr.; estípula interna elíptica, alva, paleácea, esparso-tomentosa, 13 nervuras, 2-6 × 1,5-3 mm, ápice aristado. Folha 11-22 mm compr.; pecíolo geralmente tomentoso, algumas vezes esparso-setoso, 2 $6,5 \mathrm{~mm}$ compr.; raque foliar tomentosa, $0,6-4$ mm compr; folíolo oblongo ou estreito-oblongo, ápice mucronado, base obtusa, geralmente tomentoso, algumas vezes esparso-setoso, 3-5 pares de nervuras, inconspícuas, nervuras coletoras ausentes, 6-22,5 × 1-4 mm. Inflorescência oblonga, fasciculada, congesta, terminal, axilar, 1 espiga, $(7,5-) 13-30 \times(2,5-)$ 
4,5-7 mm; bráctea externa oblonga, elíptica e largo-elíptica, tomentosa, venação paralelinérvea, 4-9 nervuras, conspícuas, trifoliolada, 3,5-4,5 ×2-5 mm, ápice cuspidado, 1-3 mm compr., base truncada; bráctea interna ausente; 2 bractéolas, oblongas, lineares, externamente glabras, internamente tomentosas, ápice aristado. Flor 9,5-12,5 mm compr.; corola amarela; estandarte orbicular, ápice obcordado, base cuneada, mácula vermelho-vinácea, 1 dobra na região basal, 4-7 × 4-6,5 $\mathrm{mm}$; asa largo-obovada, 2-4 × 1,1-2,5 mm; pétalas da quilha falciformes, 3-4 × 1-1,6 mm. Lomento com 1 artículo, segundo artículo vestigial, ovóide, largo-elíptico, pubescente ou esparso-tomentoso, 3-3,5 × 1,5-2 mm; estilete residual uncinado, 1,5-2,6 mm compr.; semente elíptica, amarela ou marrom-escura, 2,5 × 1-1,5 mm.

Material examinado: BRASIL. MATO GROSSODO SUL. Corumbá, fl. e fr., 28.XI.2006, L. C. Costa 396 (CGMS); Porto Murtinho, 3.IX.2003, fl. e fr., A. Pott \& V. J. Pott 11451 (HMS).

Stylosanthes humilis é facilmente reconhecida pelo lomento pubescente ou esparso-tomentoso provido de um artículo e ausência do eixo rudimentar plumoso. Possui fruto com um estilete residual uncinado o que a diferencia prontamente de $S$. hamata (estilete residual encurvado) e $S$. linearifolia (estilete residual espiralado).

Esta espécie possui registro para o Amazonas, Pará, Maranhão, Piauí, Ceará, Paraíba, Pernambuco, Bahia, Minas Gerais e Goiás (Brandão \& Costa 1979). Neste estudo S. humilis foi verificada nas regiões sudoeste e noroeste de Mato Grosso do Sul, sendo sua ocorrência inédita para o estado (Fig. 1b). Ocorre em savana (cerrado) e savana gramíneo-lenhosa (campo-sujo). Floresce e frutifica de setembro a novembro.

2.7 Stylosanthes linearifolia M. B. Ferreira $\&$ Souza Costa, Soc. Bot. Brasil Anais. 28 Congr. Nac. Bot.: 102. $1977 . \quad$ Figs. 7 n-c2; 1c

Subarbusto, 14-22 cm alt., ereto; ramos geralmente esparso-tomentosos, algumas vezes setosos; estípula externa oblongo ou elíptica, verde ou verde com vermelho-vináceo, geralmente setosa, algumas vezes esparsotomentosa, 10-21 nervuras, 10-18,5 ×2-5 mm, ápice subulado, 3,8-5,5 mm compr.; estípula interna ovóide a largo-ovóide, verde-clara, hialina, glabra, 4-6 nervuras, 5-6,5 × 1,5-2,5 $\mathrm{mm}$, ápice aristado. Folha $12-40 \mathrm{~mm}$ compr.; pecíolo tomentoso, 3-8,5 $\mathrm{mm}$ compr.; raque foliar tomentoso, 1-4 mm compr.; folíolo geralmente linear, raro lanceolado, ápice apiculado, base obtusa, geralmente esparsotomentoso, às vezes pubescente, 6-10 pares de nervuras, inconspícuas, nervuras coletoras ausentes, 5-29,5 × 1-3 mm. Inflorescência oblonga, fasciculada, congesta, terminal, 1-2 espigas, 14-22,5 × 3-11 (-15) mm; bráctea externa elíptica, largo-elíptica, geralmente tomentosa, algumas vezes setosa, venação paralelinérvea, 7-14 nervuras, conspícuas, unifoliolada, 5-12×3-5 mm, ápice cuspidado, 3,4-4,5 mm compr., base amplexicaule; bráctea interna largo-elíptica ou oblonga, setosa, 3-5 nervuras, 4-6,5×2-3,5 mm, ápice aristado, base amplexicaule; 2 bractéolas, lanceoladas ou lineares, glabras, ápice aristado. Flor 10-12 mm compr.; corola amarela; estandarte orbicular, ápice emarginado, base atenuada, mácula vermelho-vinácea, 1 dobra na região basal, 5-6 $\times$ 4-6 mm; asa espatulada ou largo-obovada, 3-4 × 1-2 mm, compr.; pétalas da quilha falciformes, 3,2-4×1,1-1,2 mm. Lomento com 2 artículos, oblongo ou elíptico, denso-tomentoso, 2,5-5 × 1-2 mm; estilete residual espiralado, 1-1,2 mm; semente largo-elíptica ou largooblonga, amarela, amarela pintalgada de vermelho-vináceo ou preta, 1,5-2,5×1-1,5 mm. Material examinado: BRASIL. MATO GROSSODO SUL. Aquidauana, 6.V.2002, fl. e fr., V. J. Pott et al. 5468 (HMS); Dourados, 1979, fl. e fr., A. Krapovickas 32867 (MBM); Piraputanga, 2.X.2006, fl. e fr., L. C. Costa 390 (CGMS); idem, fl. e fr., 18.II.1970, G. Hatschbach 23788 (MBM); Rio Verde de Mato Grosso, 9.VI.1994, fl., G. Hatschbach 33959 (MBM, PANG); São Gabriel d'Oeste, 15.VI.2002, fl. e fr., $A$. Pott et al. 10054 (HMS).

Stylosanthes linearifolia caracteriza-se pela bráctea externa com ápice cuspidado, folíolos geralmente lineares, lomento com 2 artículos, denso-tomentosos e estilete residual espiralado. 


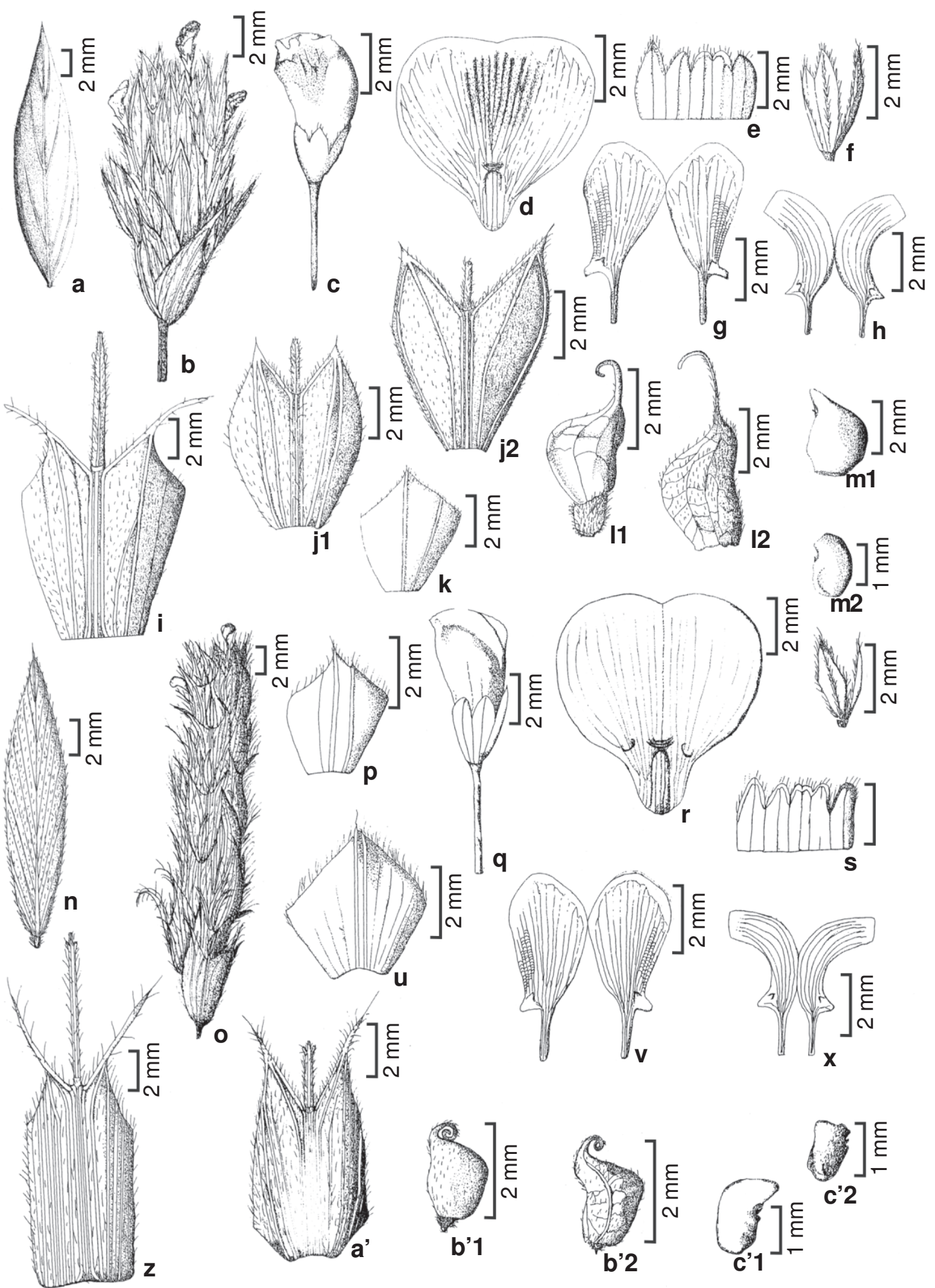

Figura 7 -a-m2. Stylosanthes humilis Kunth. - a. folíolo; b. inflorescência; c. flor; d. estandarte; e. cálice; f. bractéolas; g. asas; h. pétalas da quilha; i. estípula; j1-j2. brácteas externas; $\mathrm{k}$. bráctea interna; $11-12$. frutos; $\mathrm{m} 1$. semente artículo superior; $\mathrm{m} 2$. semente artículo inferior; n-c2. S. linearifolia M. B. Ferreira \& Souza Costa -n. folíolo; o. inflorescência; p. bráctea interna; q. flor; r. estandarte; s. cálice; t. bractéolas; u. estípula interna; v. asas; x. pétalas da quilha; z. estípula externa; a'. bráctea externa; b'1-b'2. fruto; c'1. semente do artículo superior; c'2. semente artículo inferior (a-m2 Costa 396; n-c2 Costa 390). 
Os espécimes de $S$. linearifolia coletados em Mato Grosso do Sul não apresentam eixo rudimentar plumoso e as flores têm duas bractéolas internas, característicos de Stylosanthes seção Stylosanthes. Desta forma, optou-se pela classificação de $S$. linearifolia na seção supracitada.

A espécie tem ocorrência constatada em Minas Gerais (Brandão \& Costa 1979) e é inédita para Mato Grosso do Sul, onde ocorre na região central (Fig. 1c), em savana (cerrado), savana gramíneo-lenhosa (camposujo) e savana florestada com afloramento rochoso (cerradão). Floresce e frutifica simultaneamente de maio a outubro.

2.8 Stylosanthes longiseta Micheli, Mem. Soc. Phys. Genève 28(7): 18. 1883.

Figs. 8 a-g; $1 \mathrm{~b}$

Subarbusto, ereto, $14-26 \mathrm{~cm}$ alt.; ramo geralmente denso-setoso, algumas vezes tomentoso; estípula externa obovada ou largoobovada, verde, setosa, 6-17 nervuras, 8-12 $\times 4,5-8 \mathrm{~mm}$, ápice cuspidado, 4-5,5 mm compr.; estípula interna ausente. Folha 15-36 mm compr.; pecíolo setoso, 1-2,5 mm compr.; raque foliar setosa, 1-2,5 $\mathrm{mm}$ compr.; folíolo largo-obovado a espatulado, ápice apiculado, base cuneada, setoso, 3-4 pares de nervuras, conspícuas, nervuras coletoras ausentes, (2-) 13-27,5 × 6-12,5 mm. Inflorescência ovóide, isolada, congesta, terminal, 1-2 espigas, $8,8 \times$ 6,6; bráctea externa obovada, tomentosa, venação paralelinérvea, 8-16 nervuras, conspícuas, unifoliolada, 4,5-11 × 3-7 mm, ápice cuspidado, 2,5-3,5 mm compr; bráctea interna ausente; 2 bractéolas, lineares, tomentosas, ápice aristado. Flor 10-11 mm compr.; corola amarela; estandarte largo-obovado, ápice obcordado, base cuneada, mácula vermelhovinácea, 2 dobras na parte central da pétala mais próxima à base, $6,5-7 \times 3,5-4 \mathrm{~mm}$; asa obovada, 3-3,5×1,5-2 mm; pétalas da quilha elípticas, ligeiramente falciformes, 2,7-3×1$1,5 \mathrm{~mm}$. Lomento 1 artículo, obovado, glabro, glândulas translúcidas; estilete residual uncinado, sementes elipsóides, pretas ou amarelas (Brandão \& Costa 1979; Costa 2006).
Material examinado: BRASIL. MATO GROSSODO SUL: Rio Brilhante, 23.X.1970, fl., H. Saturnino s.n. (MBM 15843).

Stylosanthes longiseta é prontamente identificada pelos ramos e folíolos setosos e folíolos largo-obovados a espatulados.

A espécie é encontrada no Paraná e Minas Gerais (Brandão \& Costa 1979). Em Mato Grosso do Sul ocorre nas região sudeste (Fig., 1b), em savana (cerrado). Flores observadas em outubro.

2.9 Stylosanthes maracajuensis Sousa Costa \& Van den Berg, Kew Bull. 58(3): 743. 2003.

Figs. 8 g-s; 1c

Subarbusto 14-22 cm alt., ereto; ramos geralmente pubescentes, algumas vezes tomentosos; estípula externa oblonga, obovada, verde com vermelho-vináceo, tomentosa, 7-9 nervuras, 4-5×2-3,5 mm, ápice subulado, 1,54 mm compr.; estípula interna ovóide, largo-ovóide, verde-clara, hialina, glabra, 1-3 nervuras, ápice aristado. Folha 15-33 mm compr., pecíolo geralmente tomentoso, algumas vezes pubescente, 2,5-9 mm compr.; raque foliar tomentosa, 1,53 mm compr.; folíolo lanceolado ou oblanceolado, ápice apiculado, base aguda ou cuneada, geralmente esparso-tomentoso, algumas vezes pubescente, pontuações em ambas as faces do folíolo, 3-5 pares de nervuras, conspícuas, nervuras coletoras ausentes, 9-18 × 2-4 mm. Inflorescência elíptica ou ovóide, fasciculada, congesta, terminal, 1-3 espigas, 14-27x 5-8,5 $\mathrm{mm}$; bráctea externa elíptica, tomentosa, venação paralelinérvea, 8-11 nervuras, conspícuas, unifoliolada, raro trifoliolada, 4-5,5 $\times 2,5-5 \mathrm{~mm}$, ápice acuminado, 1-2,5 mm compr., base amplexicaule; bráctea interna largo-oblonga ou ovóide, glabra, 3 nervuras, 3,5-4,5×2,3-3,4 mm, ápice aristado, base truncada; 2 bractéolas estreito-ovóides ou lineares, internamente densotomentosas, externamente pubescentes, ápice aristado. Flor 7-8 mm compr.; corola amarela; estandarte obcordado ou orbicular, ápice obcordado, base cuneada, mácula vermelhovinácea, 1 dobra na região basal, 4-5 ×3,5-4,5 $\mathrm{mm}$; asa largo-obovada, 2,5-3,5 × 1,6-2, mm compr.; pétalas da quilha elípticas, falciformes, 2,5-3,5 $\times 0,9-1,2 \mathrm{~mm}$. Lomento com 2 artículos, 


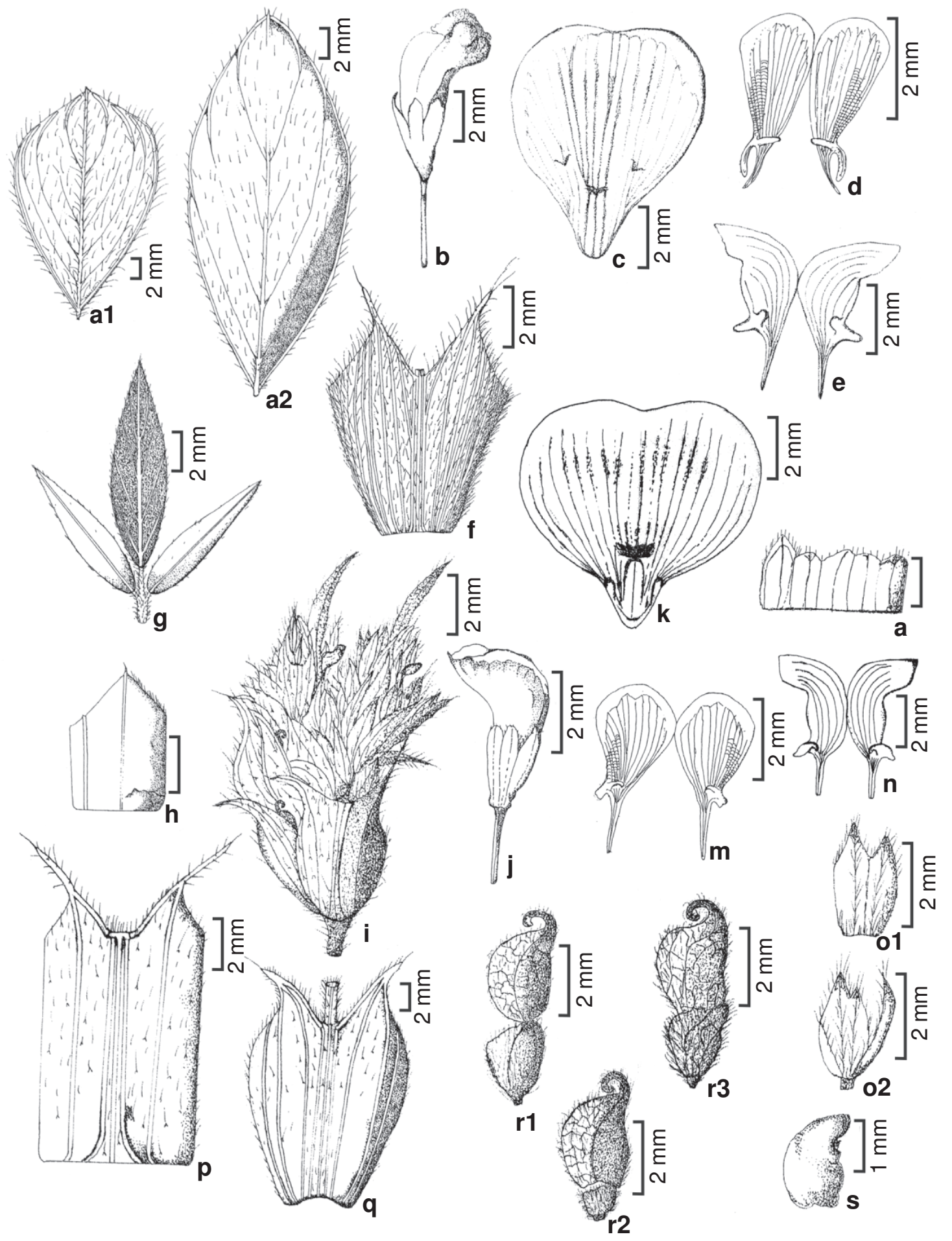

Figura 8 - a-f. Stylosanthes longiseta Micheli -a1-a2. folíolos; b. flor; c. estandarte. d. asas; e. pétalas da quilha; f. estípula externa; g-s. S. maracajuensis Souza Costa \& Van den Berg - g. folha; h. estípulas interna. i. inflorescência; j. flor; k. estandarte; 1. cálice; m. asas; n. pétalas da quilha; o1. bractéola externa; o2. bractéolas; p. estípula externa; q. bráctea externa; r1-r3. fruto; s. semente (a-f Saturnino s.n., MBM 15843; g-s Pott et al. 12568). 
oblongo, pubescente, esparso-tomentoso, 4-4,5 $\times 2,8-3,3 \mathrm{~mm}$; estilete residual uncinado, 1,5-3 mm compr.; semente oblonga ou ovóide, marromescura, amarela, 1,7-2,5 × 1-1,5 mm.

Material examinado: BRASIL. MATO GROSSODO SUL: Caracol, 10.II.1993, fl. e fr., G. Hatschbach 58848 (MBM, PANG); Corumbá, 16.III.2005, fl. e fr., A. Pott et al. 12568 (HMS); Porto Murtinho, 21.IV.2004, fl. e fr., E. L. Lescano 114 (CGMS).

Stylosanthes maracajuensis pode ser confundida com $S$. humilis e S. hamata pelo porte e forma dos folíolos, porém, difere de ambas por possuir folíolos com nervuras conspícuas, providos de pontuações.

Espécie com ocorrência restrita ao Mato Grosso do Sul (Costa \& Van den Berg 2003), ocorre em savana (cerrado) e savana florestada (cerradão), nas regiões noroeste e sudeste (Fig. 1c). Floresce e frutifica de fevereiro a abril.

2.10 Stylosanthes montevidensis Vogel, Linnaea 12:67.1838. Figs. 9 a-1; 1c

Subarbusto, 40-100 cm alt., ereto; ramo geralmente esparso-viloso, algumas vezes pubescente; estípula externa oblonga ou largooblonga, verde, setosa, 16-22 nervuras, 7-11,5 $\times$ 3-8 mm, ápice subulado, 2-6 mm compr.; estípula interna oblonga, ovóide, alva, paleácea, glabra, 16-22 nervuras, 4,5-5,5 × 3,5-6 mm. Folha 20,5-29,5 mm compr.; pecíolo setoso, 2,6-4,5 compr.; raque foliar setoso, 0,7-1,5 compr.; folíolo lanceolado ou linear, ápice apiculado, base atenuada, geralmente setoso, algumas vezes esparso-setoso, 2-4 pares de nervuras, inconspícuas, nervuras coletoras presentes, 14,5-26 × 1,2-2,6 mm. Inflorescência circular ou oblata, isolada, congesta, terminal, 6-8 espigas, 9-24 × 1218,5 mm; bráctea externa ovóide, largo-ovóide, geralmente setosa, algumas vezes densosetosa, venação paralelinérvea, 8-14 nervuras, conspícuas, unifoliolada, 3-5,5×3-7 mm, ápice caudado, 1-4,5 mm compr., base amplexicaule; bráctea interna largo-oblonga ou ovóide, glabra, 3 nervuras, 3,4-4,5 × 2,3-3,4 mm, ápice aristado, base amplexicaule; 2 bractéolas lanceoladas a lineares, externamente glabras, internamente tomentosas, ápice aristado. Flor
$8 \mathrm{~mm}$ compr.; corola amarela; estandarte largoobovado, ápice emarginado, base atenuada, mácula vermelho-vinácea, 1 dobra na região basal, 4,5 ×3,3 mm; asa obovada, 2,8 $\times 2 \mathrm{~mm}$; pétalas da quilha falciformes, $2 \times 1 \mathrm{~mm}$. Lomento com 1 artículo, elíptico, esparso-tomentoso, 44,5 × 2,8-3,3 mm.; estilete residual uncinado, 2,4-3,2 mm compr.; semente elíptica ou ovóide, marrom-escura, preta, 2-2,6 × 1-1,6 mm.

Material examinado: BRASIL. MATO GROSSODO SUL: Dourados, 24.I.1979, fr., H. Saturnino $111 e$ 114 (PANG); Ponta Porã, XII.1979, fl. fr., $H$. Saturnino 120 (PANG).

Stylosanthes montevidensis diferenciase das demais espécies do gênero em Mato Grosso do Sul pela inflorescência congesta, circular ou oblata, fruto com um artículo e estilete residual uncinado.

A espécie possui registro de ocorrência em Goiás, Minas Gerais (Dutra et al. 2005), Rio de Janeiro, Paraná, Santa Catarina e Rio Grande do Sul (Brandão \& Costa 1979). Ocorre em Mato Grosso do Sul nas regiões sudoeste, sendo sua ocorrência inédita para o estado (Fig. 1c), onde é encontrada em savana (cerrado) e savana parque (campo-cerrado). Floresce e frutifica de dezembro a janeiro.

2.11 Stylosanthes nunoi M. Brandão, Daphne 2(1): 5. 1991. Figs. 9 m-a'; $1 \mathrm{~b}$

Subarbusto 40-50 cm alt., ereto; ramos denso-tomentosos; estípula externa oblonga ou elíptica, verde, verde com vermelho-vináceo, tomentosa, 14 nervuras, 9-11,5 × 3-3,5 mm, ápice subulado, 2-4 mm compr.; estípula interna oblonga, alva, paleácea, esparsosetosa, 2-5 nervuras, (4,5-) 6-10 × 2-3 mm, ápice aristado. Folha 18-31 mm compr.; pecíolo tomentoso, 3-7 $\mathrm{mm}$ compr., raque tomentosa foliar, 0,9-1,5 mm compr.; folíolo linear ou lanceolado, ápice mucronado, base aguda, geralmente pubescente, algumas vezes esparso-tomentoso, 4-8 pares de nervuras, inconspícuas, nervuras coletoras ausentes, 16$25 \times 2-4$ mm. Inflorescência ovóide, largoovóide, fasciculada, congesta, terminal e axilar, 1-3 espigas, 12-15×7-11 mm; bráctea externa ovóide, largo-elíptica, geralmente denso- 


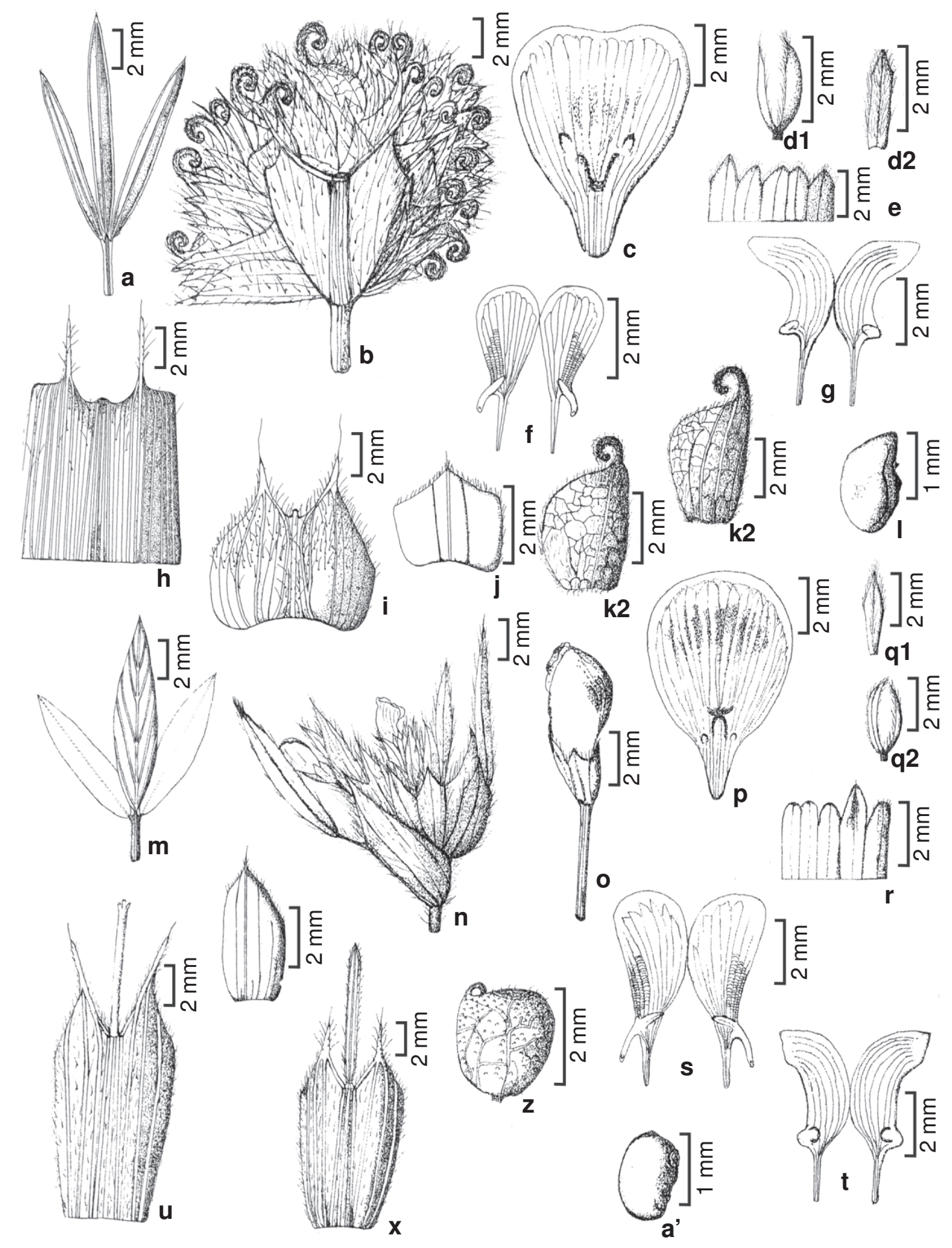

Figura 9-a-1. Stylosanthes montevidensis Vogel - a. folha; b. inflorescência; c. estandarte; d1. bractéolas; d2. bractéola; e. cálice; f. asas; g. pétalas da quilha; h. estípula; i. bráctea externa; j. bráctea interna; k1-k2. frutos; 1. semente; m-a'. S. nunoi M. Brandão - m. folha; n. inflorescência; o. flor; p. estandarte; q1. bractéola; q2. bractéolas. r. cálice; s. asas; t. pétalas da quilha; u. estípula externa; v. estípulas interna; x. bráctea externa; z. fruto; a'. semente (a-1 Saturnino 120; m-a’ Krapovickas s.n., PANG 9162). 
tomentosa, algumas vezes setosa, venação paralelinérvea, 8-12 nervuras, conspícuas, trifoliolada, 4-7 ×2-4 mm, ápice acuminado, 0,7-2,5 mm compr., base amplexicaule; bráctea interna triangular, pubescente, 3-4 nervuras, 4,5 × 2-2,9 mm, ápice aristado, base amplexicaule; 2 bractéolas lanceoladas, externamente glabras, internamente densotomentosas, ápice aristado, 4-5×0,8-0,9 mm. Flor $11 \mathrm{~mm}$ compr; corola amarelo-clara; estandarte obcordado ou largo-obovado, ápice obcordado, base cuneada, mácula vermelhovinácea, 2 dobras na região basal da pétala, $6,6 \times 4,3 \mathrm{~mm}$; asa oblonga, ca. $3 \times 1,5 \mathrm{~mm}$, pétalas da quilha oblongas, 3,3 $\times 1,3 \mathrm{~mm}$. Lomento com 2 artículos, obovado, glabro, ca. $2,9 \times 2 \mathrm{~mm}$, estilete residual espiralado, ca. 0,7 mm compr.; semente oblonga, marromescura, ca. 1,4 × 1,1 mm.

Material examinado: BRASIL. MATO GROSSODO SUL: Campo Grande, 1979, fl. e fr., A. Krapovickas s.n. (PANG 9162).

Stylosanthes nunoi e S. hippocampoides possuem estípula externa oblonga e elíptica e bráctea externa largo-elíptica. Entretanto, $S$. nunoi possui lomento com 2 artículos, estilete residual espiralado versus 1 artículo e estilete residual encurvado em $S$. hippocampoides.

É registrada em Minas Gerais e Mato Grosso (Brandão \& Costa 1979), sendo inédita em Mato Grosso do Sul onde ocorre na região central (Fig. 1b), em savana (cerrado) e savana gramíneo-lenhosa (campo sujo). Período de floração e frutificação em Mato Grosso do Sul e desconhecidos.

2.12 Stylosanthes viscosa (L.) Sw., Prod. 108. 1788.

Figs. $10 \mathrm{a}-\mathrm{m} ; 1 \mathrm{~b}$

Subarbusto $20-50 \mathrm{~cm}$ alt., ereto, raro prostrado; ramo densamente viloso, algumas vezes setoso; estípula externa largo-oblonga, ovóide, verde, denso-tomentosa, 5-11 nervuras, 3,5-6×2-5 mm, ápice subulado $2-$ $4,5 \mathrm{~mm}$ compr.; estípula interna oblonga, alva, paleácea, pubescente ou esparsamente tomentosa, 1-2 nervuras, 3-5,5 × 2-4 mm; ápice caudado. Folha 9-21,5 mm compr.; pecíolo tomentoso, 2,3-5,7 compr., raque foliar tomentoso, 0,5-2 mm compr.; folíolo elíptico a largo-elíptico, ápice mucronado ou apiculado, base obtusa, tomentoso, tricomas glandulares presentes, 3-5 pares de nervuras, inconspícuas, nervuras coletoras ausentes, 5,5-16, × 2,5-5,6 $\mathrm{mm}$ compr. Inflorescência oblonga, fasciculada, congesta, terminal, 1-2 espigas, 17-30 × 5-10 mm; bráctea externa oblonga, ovóide, geralmente denso-tomentoso algumas vezes setosa, tricomas glandulares, venação paralelinérvea, 5-8 nervuras, conspícuas, unifoliolada, 4-5 × 3,5-5,5 mm, ápice acuminado, 1-2,6 mm compr., base truncada; bráctea interna ausente; 2 bractéolas lanceoladas, ovóides, glabras, ápice aristado. Flor 7,5-8,5 mm compr.; corola amarela; estandarte obcordado ou orbicular, ápice obcordado, base atenuada, mácula vermelhovinácea, 2 dobra na região basal, 4,5-5 ×4,3$5 \mathrm{~mm}$; asa largo-obovada ou espatulada, $3-$ 3,2 x. 1,5-2 mm; pétalas da quilha falciformes, $2-3 \times 1-1,5 \mathrm{~mm}$. Lomento com 1-2 artículos, obovado, esparso-setoso, esparso-tomentoso, $2-5,5 \times 1,5-2,5 \mathrm{~mm}$; estilete residual espiralado, 0,7-0,8 mm compr.; semente ovóide, amarela, amarelo-ocre ou preta, 1-2× $1-1,5 \mathrm{~mm}$.

Material examinado: BRASIL. MATO GROSSODO SUL: Campo Grande, fl. e fr., 24.VII.2005, L. C. Costa 367 (CGMS); Nova Andradina, 4.I.2002, fl., fr., V. J. Pott \& A. Pott 5044 (HMS). Porto Murtinho 10.IX.2002, fl. e fr., A. Pott et al. 10587 (HMS).

Em Stylosanthes viscosa as brácteas externas possuem tricomas glandulares, o que confere odor característico à mesma. Possui brácteas externas com venação paralelinérvea e estandarte com 2 dobras na região basal enquanto $S$. scabra espécie morfologicamente semelhante possui venação campilódroma e estandarte com 1 dobra na região mediana.

Esta espécie ocorre na Bahia, Minas Gerais e São Paulo (Brandão \& Costa 1979). Em Mato Grosso do Sul é encontrada nas regiões central, sul, sudeste e sudoeste (Fig. 1b), em savana (cerrado), savana florestada (cerradão), geralmente associada a $S$. guianensis. Espécie perene, com flor e fruto registrados e observados durante todo o ano. 

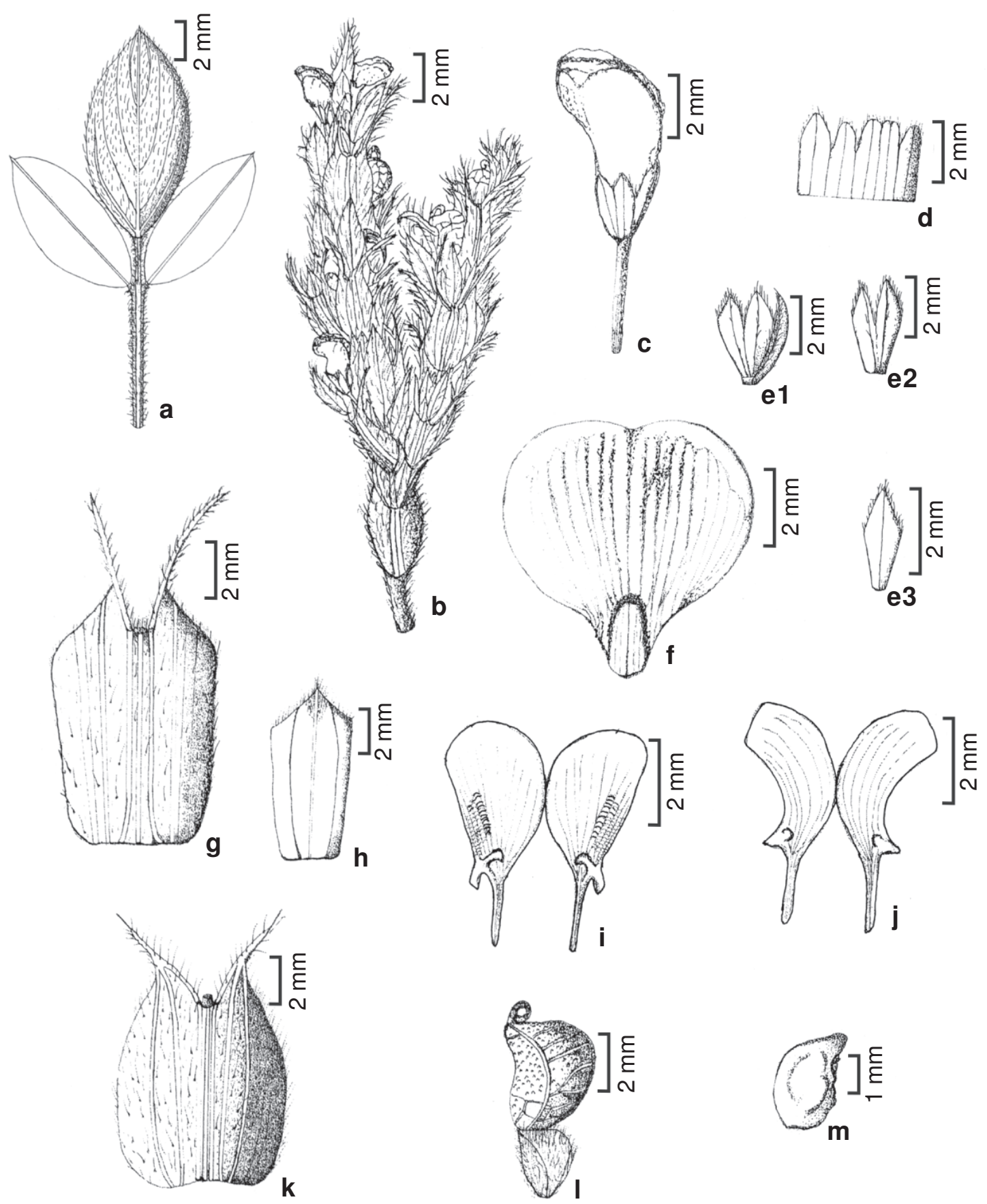

b
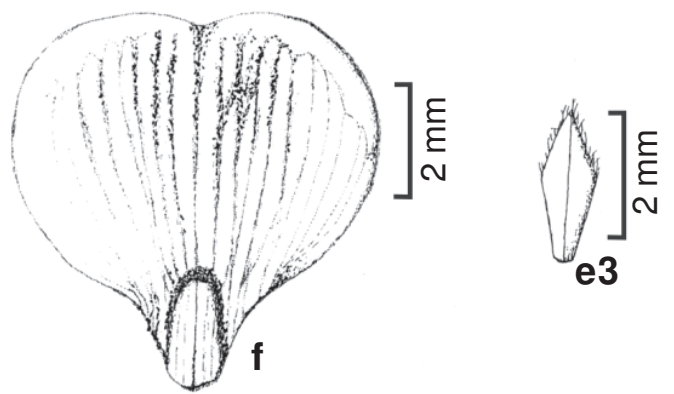

Figura 10 - a-m. Stylosanthes viscosa Sw. - a. folha; b inflorescência; c. flor; d. cálice; e1. bractéolas; e2. bractéola; e3. bractéola, f. estandarte; g. estípulas externa; h. estípula interna; i. asas; j. pétalas da quilha; k. bráctea; 1. fruto; m. semente (a-m Costa 367). 


\section{Agradecimentos}

Os autores agradecem aos curadores dos herbários pelo empréstimo das exsicatas, à Coordenação do Curso do Mestrado em Biologia Vegetal da UFMS, a CAPES (Coordenação de Aperfeiçoamento de Pessoal de Nível Superior) pela bolsa de mestrado concedida à primeira autora, a Pró-Reitoria de pesquisa e Pós-graduação, pelo auxílio nas excursões de campo e aos membros da banca pelas valiosas sugestões.

\section{REFERÊNCIAS BIBLIOGRÁFICAS}

Brandão, M. B. \& Costa, N. M. S. 1979. O gênero Stylosanthes Swartz no Brasil. Epamig, Minas Gerais, 107p. . 1982. O gênero Stylosanthes Swartz no Estado de Minas Gerais. Epamig, 52p.

Costa, N. M. S. \& Van den Berg, C. 2003. A new species of Stylosanthes Swartz (Leguminosae-Papilionoideae) from Mato Grosso do Sul, Brazil. Kew Bulletim 58(3): 743-747.

Costa, N. M. S. 2006. Revisão do Gênero de Stylosanthes Sw. Tese de Doutorado. Universidade Técnica de Lisboa Instituto Superior de Agronomia, Lisboa, 470p.

Dubs, B. 1998. Prodomus Flora Matogrossensis. Betrona Verlag, Kusnacht, 444p.

Dutra, V. F.; Messias, M. C. T. B. \& Garcia, F. C. P. 2005. Papilionoideae (Leguminosae) nos campos ferruginosos do Parque Estadual do Itacolomi, Minas Gerais, Brasil: Florística e Fenologia. Revista Brasileira de Botânica 28(3): 493-504.

Font Quer, P. 1953. Diccionario de botánica. Labor S. A. Barcelona, 1244p.

Harris, J. G. \& Harris, M. W. 1994. Plant identification terminology: an illustrated glossary. Spring Lake, 198p.

Holmgren, P. K.; Holmgren, N. H. \& Barnet, L. C. 1990. Index Herbariorum of the world. 8ed. The New York Botanical Garden, New York, 693p.

IBGE. 1992. Manual Técnico da Vegetação Brasileira. Fundação Instituto Brasileiro de Geografia e Estatística, Rio de Janeiro, 89p.

Kirkbride Junior, J. H. \& Kirkbride, M. C. G. 1987. Typification of Stylosanthes (Leguminosae) and its Sections. Taxon 36(2): 455-458.

Lewis, G. L.; Mackinder B. \& Lock, M. 2005. Legumes of the World. Royal Botanic Gardens, Kew, 578p.

Mannetje, L.'t 1977. A revision of varieties of Stylosanthes guianensis (Aubl.) Sw. Australian Journal Botanical 25(3): 347-362.

Mohlenbrock, R. H. 1958. A revision of the genus Stylosanthes. Annals of the Missouri Botanical Garden 44(4): 299-355. 1963. Further consideration in Stylosanthes (Leguminosae). Rhodora (63): 245-258.

Radford, A. E.; Dickison, W.C.; Massey, J. R. \& Bell, C. R. 1974. Vascular plant systematics. Harper \& Row, New York, 891p.

Rizzini, C.T. 1977. Sistematização e terminologia da folha. Rodriguésia 29(42): 103-125.

Rudd, V.E. 1981. Aeschynomeneae (Benth.) Hutch. In: Polhill R. M. \& Raven P.H. (eds.). Advances in Legume Systematics. Royal Botanical Garden, Kew, v. 1, Pp. 347-354.

Sousa, D. P.; Lima, K. T; Oliveira, A. L.; Queiroz, R. F.; Fernandes Neto, R. F. P. A. G. \& Nunes, E. P. 2003. Estudo do taxon genérico Stylosanthes (Leguminosae) no estado do Ceará. In: $54^{\circ}$ Congresso de Botânica e $3^{\mathrm{a}}$ Reunião Amazônica de Botânica Resumos. Belém-Pará, 97p. 